\title{
Reviving demand-pull perspectives: The effect of demand uncertainty and stagnancy on R\&D strategy
}

\author{
José García-Quevedo $^{a}$, Gabriele Pellegrino ${ }^{\text {b c }}$, Maria Savona ${ }^{d^{*}}$
}

\begin{abstract}
This paper looks at the effects of demand uncertainty and stagnancy on firms' decisions to engage in $R \& D$ activities and the amount of financial effort devoted to these. The paper provides a number of contributions to the innovation literature: first, it adds to the revived debate on demand-pull perspectives in innovation studies by examining demand-related (lack of) incentives to invest in innovation. Second, it complements the literature on barriers to innovation by focusing on demand-related obstacles rather than the more frequently explored financial barriers. Third, it analyses whether experiencing demand barriers is a sector-specific feature. Firms active in high- or low-tech manufacturing or in knowledge intensive or low-tech services might be more or less dependent on demand conditions when deciding to perform R\&D. We find that uncertain demand and lack of demand are perceived as two quite distinct barriers. While the perception of a lack of demand has a marked negative impact not only on the amount of investment in R\&D but also the likelihood of firms to engage in R\&D activities, demand uncertainty seems, on the contrary, to represent an incentive to spend more in R\&D, although only in low-tech sectors. We interpret this evidence in terms of the specific phase of the innovation cycle in which decisions to invest in $R \& D$ are taken. Sectoral affiliation seems to be playing a role only for demand uncertainty, supporting the conjecture that positive expectations on the presence of adequate market demand are a necessary condition to invest in R\&D.
\end{abstract}

Keywords: R\&D strategy, Barriers to innovation, Demand uncertainty, Lack of demand, Innovative inputs, Panel data

JEL Classification: $\mathrm{C} 23 \mathrm{O} 31 \mathrm{O} 32 \mathrm{O} 33$

${ }^{a}$ Department of Economics and Barcelona Institute of Economics - University of Barcelona, Barcelona.

${ }^{\mathrm{b}}$ World Intellectual Property Organization, Economics and Statistics Division, Geneve

${ }^{c}$ EPFL, College of Management of Technology, Lausanne

E-mails: jgarciaq@ub.edu; gabriele-pellegrino@hotmail.it.

${ }^{*}$ Corresponding author at SPRU, Science Policy Research Unit, Jubilee Building, University of Sussex, Brighton BN1 9SL, UK. E-mail: M.Savona@sussex.ac.uk and Faculty of Economics and Social Sciences, University of Lille 1, France.

Acknowledgements: A previous version of this paper was presented at the Workshop on Economics of Innovation, Complexity and Knowledge (VPDE-BRICK, Turin, December, 2013) and the Southampton Management School. We are grateful for all the comments from participants and particularly to D. Czarnitzki, F. Rentocchini and M. Vivarelli. We also thank two anonymous referees for the relevant suggestions to improve a previous version of the paper. José Garcia-Quevedo and Gabriele Pellegrino gratefully acknowledge support from the Spanish Ministry of Science and Education (ECO2010-16934). José Garcia-Quevedo is also grateful for support from the Generalitat of Catalonia (2014SGR420). The usual caveat applies. 


\section{Introduction}

The closely connected influences of demand and technological opportunities on the strategic decisions of firms to innovate and the aggregate outcomes of these decisions are well established subjects of research in innovation studies, since the seminal contribution of Schmookler (1966). This has been followed by a fierce debate among scholars in the field (Mowery and Rosenberg, 1979) and been recently revamped. Di Stefano et al. (2012) review this debate by examining the evolution of scholars' positions either in favour of a technologypush or a demand-pull source of innovation and their relative importance in fostering innovation.

Interestingly, to our knowledge no previous study has analysed the demand-pull perspective from the viewpoint of barriers to innovation. Analyses of the factors of innovation success are proportionally more numerous in the innovation literature than studies of failures and the effect of the lack of incentives to engage in innovation. Demand-pull perspectives seem therefore to have overlooked the lack of or uncertainty around demand as factors hampering decisions to invest in innovation.

The flourishing literature on barriers to innovation has dealt primarily with the firms' characteristics that affect their perception of barriers to innovation or, when specifically examining the actual hindrances of perceived barriers, it has paid a disproportionate amount of interest to financial barriers and limitations to the financial capacity of firms to invest in R\&D (see Hall et al., 2015, D'Este et al., 2012, and Pellegrino and Savona, 2013, for reviews of this literature). This bias toward financial obstacles might well reflect the relative dominance of technology-push perspectives over interest in demand-related incentives to innovate. 
Rather than contrasting the two perspectives empirically, here we seek to rebalance the overall picture by attempting to disentangle the effects of lack of demand, or perceived uncertainty about demand conditions, on firms' decisions to invest in R\&D and the amount of resources they devote to the activity. The paper makes a number of contributions to the innovation literature: first, it adds to the revived debate on demand-pull perspectives in innovation studies, by examining demand-related (i.e., lack of) incentives to invest in innovation. Second, it complements the growing literature on barriers to innovation in two ways: on the one hand, by focusing on demand-related obstacles rather than on the more frequently explored financial barriers; and, on the other, by analysing in detail whether experiencing demand-related obstacles is a sector-specific feature, that is, whether firms active in high- or low-tech manufacturing or in knowledge intensive or low-tech services are more or less dependent on demand conditions when deciding to perform R\&D.

We find that demand uncertainty and stagnancy are two quite distinct barriers, having substantially different effects on firms' behaviour. We interpret this evidence in terms of the specific phase in the innovation cycle in which decisions to invest in $R \& D$ are formulated. While demand uncertainty has a weak, positive statistically significant effect on R\&D plans, the perception of a lack of demand has a marked negative impact not only on the amount of investment in $R \& D$ but also the likelihood of firms engaging in $R \& D$ activities. Sectoral affiliation seems to be playing a role only for demand uncertainty, supporting the conjecture that positive expectations on the presence of adequate market demand are a necessary condition to invest in R\&D.

In the following section we briefly review the two sets of literature mentioned above: studies comparing demand-pull vs. technology-push sources of innovation and analyses of barriers to innovation. Section 3 describes the data employed in the empirical analysis; 
Section 4 illustrates the econometric strategy and the variables used in the estimations, while Section 5 discusses the results. Section 6 concludes.

\section{Background literature}

\subsection{Demand-pull perspectives revisited}

The innovation literature has traditionally been ambivalent on the role of demand as an incentive to innovation, besides that of technological opportunities. As suggested by Di Stefano et al., (2012), the debate between demand-pull and technology-push perspectives has evolved through different stages, from the rigid adoption of opposing stances by the supporters of demand-pull (Schmookler, 1962, 1966; Myers and Marquis, 1969; von Hippel, 1978, 1982) and its critics (Mowery and Rosenberg, 1979; Dosi, 1982; Kleinknecht and Verspagen, 1990) before settling, more recently, for a more balanced view which sees demand as a complementary (though not dominant) factor determining innovation. This body of literature includes both conceptual and empirical contributions (Cainelli et al., 2006; Piva and Vivarelli, 2007; Fontana and Guerzoni, 2008) as well as analyses conducted at both macro- and firm-levels.

For the purposes of our discussion here, it should suffice to recall the main arguments in the debate, relate them to the most recent literature on barriers to innovation (Section 2.2) and formulate the conjectures (Section 2.3) that we then test empirically in the remaining of the paper.

As Fontana and Guerzoni (2008) suggest, the intuition regarding the influence of demand on innovation was sparked by the seminal contributions by Schmookler $(1962 ; 1966)$ and Myers and Marquis (1969), who claimed that the introduction of new products and processes is conditioned by the presence of demand or even possibly a latent demand and, in general, by positive expectations of profitability from returns to innovation. In the absence of 
these conditions, firms would simply not have any incentive to innovate. Moreover, the adoption and diffusion of (radically) new products are intrinsically subject to uncertainty, which would further reduce incentives to innovate. The arguments put forward by the supporters of technology-push types of innovation incentives touched upon various issues, ranging from the reverse causality of the empirical relationships estimated by Schmookler (1966) and Meyers and Marquis (1969) to the difficulties of identifying the relevant demand affecting innovation incentives.

It is our contention, and one we come back to later, that market size - and therefore expectations regarding profitability - and demand uncertainty are very likely to refer to different levels of demand. First, positive expectations with regard to profitability and, hence, incentives to innovate, despite being intrinsically linked to the fate of the new product being launched, are affected primarily by the macro-conditions of aggregate demand and the market dynamism of the specific and related products. Even incremental product or process innovation would be hard to implement if prospects of returns to innovation were dim.

Second, while uncertainty might be linked to aggregate macro-conditions of demand, it is predominantly affected by the characteristics of the new products/services and the lack of information on users and their capabilities to adopt/benefit from the new product (see also von Tunzelmann and Wang, 2003 on user capabilities). ${ }^{1}$

Of course, macro- and micro-demand conditions are likely to reinforce each other, though in the case of incremental product or process innovation, aggregate stagnancy of demand might be more influential, whereas in the case of radically new products or services it is the uncertainty that is likely to play a major role in terms of incentives to innovate (see also Fontana and Guerzoni, 2008).

\footnotetext{
${ }^{1}$ Relatedly, a "competent demand-pull hypothesis" has been recently put forward, that claims that often the demand-pull effect is enhanced when users have advanced competences and skills and are able to increase the demand for sophisticated products, thereby inducing innovation efforts (Antonelli and Gehringer, 2015).
} 


\subsection{Demand as a barrier to innovation: stagnancy and uncertainty}

Although the literature on barriers to innovation is relatively recent, scholars have found substantial evidence of the presence and effects of perceived hindrances on the propensity and intensity of engagement in innovation activities.

A large proportion of these studies have focused their attention on analyses of the effects of financial constraints on firms' cash flow sensitivity to afford R\&D investments (for a review, see Schiantarelli, 1996; Hall, 2002; Bond et al., 1999; Hottenrott and Peters, 2012; Hall et al., 2015). Indeed, empirical evidence tends to confirm that encountering financial constraints significantly lowers the likelihood of firms engaging in innovative activities (Savignac, 2008), with this pattern being more pronounced in small firms and in high-tech sectors (Canepa and Stoneman, 2008; Hall, 2008; Hottenrott and Peters, 2012).

The implicit assumption behind most of the contribution focusing on financial barriers is that it is essentially access to finance, financial uncertainty and information asymmetries that reduce the financial returns of $R \& D$ investments and the ability to attract external funds, thus reducing incentives to invest in $R \& D$.

A few recent contributions have extended the analysis to non-financial obstacles to innovation, drawing primarily on evidence from innovation surveys, which allow the effects of knowledge-related obstacles (e.g., shortage of qualified employees, lack of information on technology and markets), market-related obstacles (e.g., lack of customer interest in innovative products, markets dominated by large incumbents), and barriers attributable to the need to fulfil national and international regulations) to be examined. Moreover, these innovation surveys allow researchers to look beyond the mere decision to invest in R\&D and to take into account innovation outputs, such as the introduction of a new (to the market or to the firm) good or service or a new process. More recently, these analyses have been extended 
to the effect of barriers on the economic performance of firms, through innovation (Coad et al., 2015)

Even within the CIS-based literature, an overwhelming number of contributions focus on the financial constraints to innovation, treating the role of non-financial constraints as a simple control factor (Tiwari et al., 2008; Mancusi and Vezzulli, 2010; Blanchard et al., 2013). Analyses of factors affecting the perception of all types of obstacles are provided, however, by Iammarino et al. (2009) and D'Este et al. (2008 and 2012). Pellegrino and Savona (2013) look at the effect of all types of barriers on the likelihood of being a successful innovator, recognizing the fundamental - possibly exacerbating - impact of other types of obstacles indirectly on the financial barriers and directly on the innovation intensity of firms. All these contributions point equally to the importance of the lack of access to finance and the lack of market responses to innovation.

\subsection{Main conjectures}

Overall, the implicit assumption behind what we consider to be a bias toward technology-push perspectives within the innovation literature is that firms plan their innovation investments in a context that is structurally and indefinitely capable of absorbing any innovation outputs, somewhat in line with a version of the Say's Law $^{2}$ for innovative products. This would apply both at the general macro-economic level - that is, a general state of dynamism of aggregate consumption - and at the micro-level of analysis - that is, for the specific product/service/sector that has been introduced onto the market.

\footnotetext{
${ }^{2}$ Put simply, Jean Baptiste Say claimed that "supply always creates its own demand" - i.e., markets are able to infinitely absorb any quantity of production. The Keynesian framework overall rejected Say's Law. Here we stretch the argument and argue that in the case of innovative products, the uncertainty of whether the launch of new products or services is going to be adopted by consumers and diffused in the markets is even higher than that affecting standard plans of production.
} 
While we do not attempt to test the technology-push and demand-pull hypotheses empirically, here we contest this assumption and claim that if easy access to finance and the availability of funds are important conditions to implement innovation investment plans, trust and positive expectations on the state of demand are necessary conditions for firms to enter the innovation contest and initiate innovation investment plans.

Rather than focusing on market structure issues or "lack of customer interest", we turn our attention to firms' perception of the state of demand in terms of both the lack of demand tout court and market uncertainty. As far as the latter is concerned, we are aware that some scholars (see, for instance, Czarnitzki and Toole, 2011 and 2013) have analysed the effect of market uncertainty on $R \& D$ investment behaviour from a real option theory perspective, finding that uncertainty causes a fall in $R \& D$ investments, albeit mitigated by patent protection (Czarnitzki and Toole, 2011) and firms' size and market concentration (Czarnitzki and Toole, 2013).

Here we take a more heuristic approach to uncertainty and one that is more data driven, with the aim of testing whether firms' self-reported perception of market uncertainty ${ }^{3}$ affects their investment behaviour. Specifically, we examine whether the decision to invest in $R \& D$ and the amount of investment in $R \& D$ are affected by perceptions of these two demand-related obstacles over time and we empirically test this within a panel econometrics framework, as detailed in the next section.

Further, an important added value of this paper is the analysis it undertakes of possible sectoral differences in the way demand affects firms' propensity to invest in R\&D. ${ }^{4}$

\footnotetext{
${ }^{3}$ As explained in Section 3, information on market uncertainty is based on responses to a specific question formulated in terms of whether "uncertain demand for innovative goods or services" is perceived as a barrier to innovation. We believe that despite the qualitative, self-report nature of the information provided by this question (in common with all CIS-based evidence), it allows us to draw a plausible picture of firms' responses to increasing levels of (perceived) uncertainty.

${ }^{4}$ In the best tradition of innovation studies, this allows us to control for the role of different technological opportunities at the sectoral level and, therefore, to implicitly account for the "technology-push" argument.
} 
Our conjecture is that service firms are substantially more sensitive to the state of demand when planning their innovative strategies. This is in line with much of the literature on innovation in services (for a review, see Gallouj and Savona, 2009), which claims that the importance of customers and user-producer interactions in services is substantially higher than in manufacturing sectors. Accordingly, we empirically test the conjectures above for both the whole sample of firms and for sub-samples of different macro-sectors, as explained in detail below.

\section{Data}

We draw on firm level data from the Spanish Technological Innovation Panel (PITEC), compiled jointly by the Spanish National Statistics Institute (INE), the Spanish Foundation for Science and Technology (FECYT), and the Foundation for Technical Innovation (COTEC). The data are collected in line with the Oslo Manual guidelines (OECD, 1997) and, as such, they can be considered to constitute a Community Innovation Survey or CIS-type dataset. Thus, together with general information about the firm (main industry of affiliation, turnover, employment, founding year), PITEC also includes a (much larger) set of innovation variables that measure the firms' engagement in innovation activity, economic and non-economic measures of the effects of innovation, self-reported evaluations of factors hampering or fostering innovation, participation in cooperative innovation activities and some complementary innovation activities such as organisational change and marketing. ${ }^{5}$

An important feature that distinguishes PITEC from the majority of European CIStype datasets is its longitudinal nature. Since 2003 systematic data collection has ensured the

\footnotetext{
${ }^{5}$ Recent works based on the use of this dataset are López-García, et al. (2013), D’Este et al (2014) and Segarra and Teruel (2014).
} 
consistent representativeness of the population of Spanish manufacturing and service firms over a number of time periods.

In this study we use data for the period 2004-2011 and select our working database from the initial sample (100,016 firm-year observations). First, we discard all firms operating in the primary (1,628 observations), construction (3,914 observations), utilities (720 observations) and sewage/refuse disposal (318 observations) sectors and all firms involved in M\&A transactions (8,543 observations). ${ }^{6}$ In line with our previous work (D'Este et al., 2008 and 2012; Pellegrino and Savona, 2013), we then select a relevant sample. To this end, we exclude 6,114 observations that refer to "non-innovation-oriented firms", i.e., firms that did not introduce any type of innovation (goods, services or processes) and which at the same time did not encounter any barriers to innovation during the three-year period, and which we therefore infer are not interested in innovating. The resulting sample of 78,779 firm-year observations is further reduced by excluding all the missing values for the variables used in the empirical analysis (24,315 observations), as well as 354 firms that were observed for just one year.

Table 1 shows the composition of the final dataset following data cleaning. As can be seen, half of the 9,132 firms (54,110 observations) included in the final sample are observed for all eight periods (2004-2011); about 23\% are observed for seven periods while only a negligible percentage of firms (around 10\%) are observed for less than five years. These figures allow us to confirm with confidence the suitability of this dataset for the subsequent dynamic analysis.

\section{$<$ INSERT TABLE $1>$}

\footnotetext{
${ }^{6}$ It is common practice in the innovation literature to focus on private manufacturing and services companies and to exclude public utilities and primary activities owing to differences in the regulatory framework in which they operate. In the case of M\&A transactions, firms were eliminated from the sample in the years following the merger or acquisition.
} 


\section{Econometric strategy}

\subsection{Specification and variables}

As discussed above, the main aim of this paper is to assess empirically whether and, if so, to what extent demand-related obstacles to innovation affect two important innovative decisions taken by firms: their propensity to engage in $R \& D$ and, conditional on this, the level of investment in R\&D.

As stressed by a largely consolidated stream of literature, innovation and, in particular, R\&D activities are processes that present high degrees of cumulativeness and irreversibility and, as a result, are characterised by a high level of persistence (see Atkinson and Stiglitz, 1969; David, 1985; Dosi, 1988; Cefis and Orsenigo, 2001). This evidence is fully supported by our data. Indeed, if we examine the transition probabilities of engaging in $R \& D$ activities (see Table 2) it emerges that almost $86 \%$ of $R \& D$ performers in one year retained this same status during the subsequent year. This percentage rises to $91 \%$ in the case of non R\&D performers that did not change their status into the next period.

\section{< INSERT TABLE 2>}

This evidence suggests that the use of an autoregressive specification for the two decisions taken by a firm in relation to its $R \& D$ activities is the most suitable. Accordingly, our empirical strategy is based on the estimation of the following two equations:

$$
\begin{aligned}
& y_{1 i t}^{*}=\varphi_{1} y_{1 i, t-1}+\beta_{1}^{\prime} x_{i t}+c_{1 i}+\varepsilon_{1 i t} \\
& y_{2 i t}^{*}=\varphi_{2} y_{2 i, t-1}+\beta_{2}^{\prime} x_{i t}+c_{2 i}+\varepsilon_{2 i t}
\end{aligned}
$$


where $y_{1 i t}^{*}$ and $y_{2 i t}^{*}$ denote the two latent dependent variables representing respectively firm $i$ 's propensity at period $t(i=1, \ldots \mathrm{N} ; t=1, \ldots \mathrm{T})$ to engage in $\mathrm{R} \& \mathrm{D}$ (expressed as a binary variable), and firm $i$ 's decision on the level of investment in R\&D activity (the natural logarithm of R\&D expenditure). For each firm $i, y_{1 i, t-1}$ and $y_{2 i, t-1}$ represent the one-period lag of the $y_{1 i t}^{*}$ and $y_{2 i t}^{*}$ dependent variables, while $x$ is a vector of explanatory variables that has been chosen taking into account both the characteristics of the dataset at our disposal and the main insights provided by the literature on the subject.

More specifically, we first consider a binary indicator of international competition, which is equal to 1 if a firm's most significant market of destination is international and equal to 0 otherwise. On the grounds that international markets tend to be characterized by a higher level of competition, this variable should exert a positive effect on the firm's propensity to innovate (e.g., Archibugi and Iammarino, 1999; Narula and Zanfei, 2003; Cassiman et al., 2010). However, some authors (see, for example, Clerides et al., 1998) warn of the possible existence of a reverse causation: most innovative firms are more likely to penetrate foreign markets and self-select themselves so as to engage in tougher foreign competition. In order to deal with this endogeneity issue we consider the one-period lagged value of this variable.

Reverse causation has also been observed in the relationship between public subsidies and innovation activity. Most of the literature on the subject provides empirical support for the positive impact of incentive schemes on a firm's propensity to both engage in and undertake R\&D (see, for example, Callejon and García-Quevedo, 2005; González et al., 2005 for the Spanish case). However, other contributions cast some doubt on the reliability of such a relationship because of the potential endogeneity of public funding (see, for example, Wallsten, 2000). Accordingly, the t-1 value of an indicator of whether the firm has received public support for innovation is included. 
A one-period lagged value has also been considered for two indicators of whether the firm makes use respectively of patents and informal methods (registration of design, trademarks, copyrights) to protect its innovations. ${ }^{7}$ In this case, the rationale is that the positive impact of the mechanisms of appropriability used by a firm take time to manifest.

We also use a variable recording a firm's age to control for age related effects. The theoretical and empirical literatures provide mixed evidence regarding the possible effect of age on engagement in/realization of innovation activities. Klepper (1996) provides a theoretical model that points to a negative relationship between a firm's age and its probability of innovating. However, as Galende and De la Fuente (2003) point out, a firm's age can also be seen as a proxy of the firm's knowledge and experience accumulated over time and, consequently, it should be positively related to innovation.

Moreover, in line with various studies that stress the expected innovative benefits for a firm that is a member of an industrial group (see Mairesse and Mohnen, 2002), such as easier access to finance and positive intra-group knowledge spillovers, we include a dummy variable identifying this characteristic.

A further important factor that might influence a firm's R\&D decision is the business cycle. In order to control for this aspect, in line with some recent contributions (see Aghion et al., 2012; Lopez Garcia et al., 2013), we use a micro-level perspective to identify idiosyncratic shocks to firms by considering firm's sales growth.

Finally, in line with the Schumpeterian tradition, we consider a variable reporting the $\log$ of the total number of employees as a measure of firm size and a set of industry dummies variables (based on the 2-digit CNAE $\operatorname{codes}^{8}$ ).

\footnotetext{
${ }^{7}$ Previous studies generally show a clear-cut, positive link between these factors and a firm's innovative activity (see Levin et al., 1987; Salomon and Shaver, 2005; Liu and Buck, 2007).

${ }^{8}$ The Spanish industrial classification codes (CNAE) correspond to the European NACE taxonomy.
} 
In the case of the demand-related obstacles, in line with the discussion in Section 2 and the rationale underpinning this, we single out two binary variables that identify an increase (over a yearly base) in the degree of importance (irrelevant, low, medium, high) that firms assign to the two barriers, specified as "uncertain demand for innovative goods and services" and "lack of demand for innovation". 9 Finally, we control for possible additional negative effects of other obstacles to innovation, including a dichotomous variable recording an annual increase in the importance of the firm's level of perception of the remaining obstacle categories (cost and knowledge related obstacles, market dominated by established firms). Table A1 in the Appendix shows the list of variables, their acronyms and a detailed description.

\subsection{Econometric methodology}

The dynamic nature of equation (1) and (2), together with the fact that equation (2) can only be observed for those firms that invest in R\&D activities, leads us to employ an econometric methodology based on the application of a dynamic type-2 tobit model (see Ameniya, 1984).

The simultaneous estimation of the dynamic equations (1) and (2) requires to carefully take into account three methodological issues: 1) the occurrence of sample selection, since eq. (2) can only be observed for those firms that invest in R\&D activities; 2) the presence of unobserved individual effects, calling for a fixed effects or a random effects specification; 3) the correlation between the initial conditions and the individual effects: this problem occurs because the first observation referring to a dynamic variable (initial condition) is determined by the same data generation process.

\footnotetext{
${ }^{9}$ We opted to use these constructed variables in light of the high within-variation of the obstacle variables. However, by construction, the variables take the value 0 in the case of firms persistently assessing the two barriers as highly relevant. We therefore perform robustness checks by considering instead two dichotomous variables taking the value 1 when a firm evaluates as highly relevant the lack/uncertainty of demand and 0 otherwise. The results shown in tables A3-A4 and A5 in the Appendix are remarkably consistent with those discussed in Section 5.2.
} 
In order to deal jointly with these problems, we use the methodology proposed by Raymond et al. (2010). ${ }^{10}$ First, we assume the individual error terms, $c_{1 i}$ and $c_{2 i}$, to have a joint distribution and we apply a random-effects approach. Second, we treat the initial conditions problem in line with Wooldridge (2005), and assume that the unobserved individual effects depend on the initial conditions and the strictly exogenous variables:

$$
\begin{aligned}
& c_{1 i}=a_{1}^{0}+a_{1}^{1} y_{1 i 0}+a_{1}^{\prime 2} X_{i}+u_{1 i} \\
& c_{2 i}=a_{2}^{0}+a_{2}^{1} y_{2 i 0}+a_{2}^{\prime 2} X_{i}+u_{2 i}
\end{aligned}
$$

where $a_{1}^{0}$ and $a_{2}^{0}$ are constants, $y_{1 i 0}$ and $y_{2 i 0}$ are the initial values of the dependent variables and $X_{i}$ is the Mundlak within-means (1978) of $X_{i t}$. The vectors $\left(\varepsilon_{1 i t}, \varepsilon_{2 i t}\right)$ and $\left(u_{1 i}, u_{2 i}\right)$ are assumed to be independently and identically (over time and across individuals) normally distributed with means 0 and covariance matrices, equal to:

$$
\Omega_{\varepsilon 1 \varepsilon 2}=\left(\begin{array}{cc}
1 & \rho_{\varepsilon_{1} \varepsilon_{2}} \sigma_{\varepsilon_{2}} \\
\rho_{\varepsilon_{1} \varepsilon_{2}} \sigma_{\varepsilon_{2}} & \sigma_{\varepsilon_{2}}^{2}
\end{array}\right) \text { and } \Omega_{u 1 u 2}=\left(\begin{array}{cc}
\sigma_{u_{1}}^{2} & \rho_{u_{1} u_{2}} \sigma_{u_{1}} \sigma_{u_{2}} \\
\rho_{u_{1} u_{2}} \sigma_{u_{1}} \sigma_{u_{2}} & \sigma_{u_{2}}^{2}
\end{array}\right)
$$

Hence, the likelihood function of a given firm $i$, starting from $\mathrm{t}=1$ and conditional on the regressors and the initial conditions, can be written as:

$$
L_{i}=\int_{-\infty}^{\infty} \int_{-\infty}^{\infty} \prod_{t=1}^{T} L_{i t}\left(y_{1 i t}, y_{2 i t} \mid y_{1 i 0}, y_{1 i, t-1}, X_{i}, y_{2 i 0}, y_{2 i, t-1}, \mathrm{X}_{i}, u_{1 i}, u_{2 i}\right) g\left(u_{1 i}, u_{2 i}\right) d u_{1 i} d u_{2 i}
$$

\footnotetext{
${ }^{10}$ We thank the two anonymous referees inducing us to use this robust update econometric methodology.
} 
where $\prod_{t=1}^{T} L_{i t}\left(y_{1 i t}, y_{2 i t} \mid y_{1 i 0}, y_{1 i, t-1}, X_{i}, y_{2 i 0}, y_{2 i, t-1}, X_{i}, u_{1 i}, u_{2 i}\right)$ represents the likelihood function once the individual effects have been integrated out and can be treated as fixed, and $g\left(u_{1 i}, u_{2 i}\right)$ is the bivariate normal density function of $\left(u_{1 i}, u_{2 i}\right)^{\prime}$.

Finally, to take into account sample selection, equations (1) and (2) are jointly estimated by using a conditional maximum likelihood estimator and are correlated through the individual effects $\left(\rho_{u_{1} u_{2}} \neq 0\right)$ and the idiosyncratic error terms $\left(\rho_{\varepsilon_{1} \varepsilon_{2}} \neq 0\right)$. The 'total' correlation between the two equations being:

$$
\rho_{\text {tot }}=\frac{\rho_{u_{1} u_{2}} \sigma_{u_{1}} \sigma_{u_{2}}+\rho_{\varepsilon_{1} \varepsilon_{2}} \sigma_{\varepsilon_{2}}}{\sqrt{\left(\sigma_{u_{1}}^{2}+1\right)\left(\sigma_{u_{2}}^{2}+\sigma_{\varepsilon_{2}}^{2}\right)}}
$$

\section{Empirical evidence}

\subsection{Descriptive statistics}

One of the conjectures put forward in this paper is that a firm's sectoral affiliation is a major determinant of the presence and dimension of the effects of demand obstacles on its innovative behaviour. Following the classification proposed by Eurostat and based on an aggregation of NACE manufacturing and service sectors, we identify four macro-categories: high/medium-high technology manufacturing industries (HMHt), low/medium-low technology manufacturing industries (LMLt), knowledge-intensive services sectors (KIS) and less knowledge-intensive services sectors (LKIS). Table 3 reports the sectoral (2 digit) composition and the distribution of these four macro-categories and the mean of the two demand obstacle variables Lack of demand and Uncertainty for each sector. In terms of sectoral composition, there is a slight prevalence of LMLt firms, which represent $35 \%$ of total observations, while the remaining $65 \%$ of the observations are roughly equally distributed 
among the three other sectoral categories (HMHt, KIS and LKIS). These figures are consistent with the Spanish sectoral structure, which, compared to the average for the European Union, specialises in products and services with less technological content (García Delgado and Myro, 2014). Nevertheless, the presence of HMHt and KIS firms is significant, as they represent $14 \%$ and $19 \%$ respectively of the total employment of the sample. In particular, within he HMHt category, the most important industries are motor vehicles, chemicals and pharmaceuticals while for KIS is financial intermediation and insurance. If we consider the sectoral frequencies in terms of the macro-categories, around $22 \%$ of the LMLt firms operate in the food, beverage and tobacco sectors; around 29\% of HMHt companies are active in the chemical sectors; $35 \%$ of KIS firms carry out computer programming activities and, finally, $36 \%$ of the LKIS firms are active in the trade sector.

Across these four macro-sectors, almost $20 \%$ of firms have experienced an increase in the perceived degree of importance of demand uncertainty, while a lower percentage (around $16 \%$ ) experienced an increase in the degree of importance of the lack of demand as a perceived obstacle. In particular, no striking differences can be found, with a percentage range running from 13.54 (HMHt) to 17.90 (LKIS) for the Uncertainty variable and from 17.39 (HMHt) to 22.26 (LKIS) for the Lack of demand variable. Overall, these figures reveal a high sensitivity of firms to changes in the demand condition that can hamper their innovation activities. This evidence is further corroborated by the figures in Table 4, which report the mean values (in percentages) of the two demand-related obstacles by year and sectoral categories. However, these variables show a considerable within variation.

< INSERT TABLES 3 AND 4> 
Our examination of possible sectoral specificities in terms of a firm's characteristics (see Table 5 for the summary statistics - mean and standard deviation - of the variables presented above) reveals that some of the differences are in line with expectations. Specifically: 1) HMHt and KIS firms appear to be more likely to engage in R\&D, to invest more in $R \& D$ and to have a higher probability of receiving subsidies for their innovation activity (in line with the previous discussion) than the other two categories; 2) firms in the manufacturing sectors show a much higher propensity to export than those active in the services sectors; 3) while no striking sectoral differences emerge with respect to the firm's propensity to use informal methods of protection (the lowest percentage being associated, as expected, with LKIS firms), HMHt firms are more likely to protect the results of their innovation activity by means of patents than the firms operating in the other sectors (with only $5 \%$ of LKIS firms resorting to appropriability methods of this type) are. If we examine the remaining variables, on average $37 \%$ of the observations refer to firms that are part of an industrial group: this percentage ranges from $34 \%$ for firms in the LMLt category to $42 \%$ for those in the HMHt group. Finally, turning to the size $(\ln (\operatorname{Size}))$ and age $(\ln ($ Age $))$ variables, on average, firms acting in the KIS sectors appear to be younger and smaller than their counterparts in the other sectoral categories. ${ }^{11}$

\section{< INSERT TABLE 5>}

\footnotetext{
${ }^{11}$ It is worth nothing that, since we use panel data, the revealed negative relationship between R\&D and age might be due to a survivorship bias. Indeed, as the subsequent surveys can only account for firms that have survived until the date of data collection, the probability that the resulting sample may be biased towards the more successful companies is not negligible. This could be particularly true for new born and young firms which are more likely to be affected by early failure.
} 
Table 6 reports the mean values of the variables for the four different firm types identified by taking into account their "demand obstacle status". More specifically we distinguish those firms that did not experience an increase in the degree of relevance assigned to either of the two obstacles, from those that report an increase in the degree of importance of only the lack of demand obstacle; only the uncertainty demand obstacle; or both types of demand obstacle. We find that firms belonging to the first category present quite distinct characteristics from those in any of the remaining groups. Specifically, firms that did not report any increase in the degree of relevance assigned to either of the two obstacles show higher values for all the variables considered, with the exception of the variables of other obstacles and sales growth. In contrast, and as expected, firms reporting positive values for the demand obstacle variables appear to be less R\&D oriented (both in terms of the probability of conducting the activity and the level of investment) than their counterparts, and this is particularly true in the case of firms that report an increase in the level of importance of the lack of demand obstacle. This evidence is largely robust across the four sectoral categories. Albeit solely at the descriptive level, this evidence seems to suggest that, regardless of the sector, demand conditions play an important role in affecting innovative firms' decisions. We test this in an econometric framework in the next section.

\section{$<$ INSERT TABLE $6>$}

\subsection{Econometric results}

The econometric results of the dynamic panel data type-2 tobit model for the whole sample are reported in Table 7. The upper part of the table shows the estimated parameters of the main variables of interest, the demand obstacles, and the control variables, while the 
bottom part reports the coefficients of the initial conditions $\left(y_{1 i 0}, y_{2 i 0}\right)$ the crossequation correlations $\left(\rho_{u_{1}} \rho_{u_{2}}, \rho_{\varepsilon_{1} \varepsilon_{2}}\right)$ and the standard deviations of the error terms $\left(\sigma_{u_{1}}, \sigma_{u_{2}}, \sigma_{\varepsilon_{2}}\right)$.

\subsubsection{Uncertainty, lack of demand and R\&D strategies}

We first focus on our main variables of interest, and discuss the results on the control variables in the next section.

We find that an increase in the perception of demand uncertainty for innovative goods or services does not have any effect on firms' decisions to invest or not in $R \& D$, while having a positive effect on the amount of $R \& D$ invested. It should be noted that this result seems to be driven by the effect of demand uncertainty, conditional on the propensity to engage in $\mathrm{R} \& \mathrm{D}$, on $\mathrm{R} \& \mathrm{D}$ investment in low/medium-low tech manufacturing industries (see column 2 of Table 8).

As discussed in Section 2, the theoretical literature examining the relationship between uncertainty and R\&D does not offer a conclusive answer. The few empirical studies in the field seem to support a negative relationship (Czarnitzki and Toole, 2011 \& 2013), while some recent research (Stein and Stone, 2013) finds a positive relationship between uncertainty and R\&D investment, which seems to be supported by the results of our estimations. The evidence of firms opting to invest or devote more of their budget to R\&D in response to increases in the perceived level of demand uncertainty is confined, in our results, to the sub-sample of firms in the low/medium low tech sectors only. As a consequence, we interpret this to be a sector-specific defensive strategy in response to an increase in the perceived uncertainty of demand, in markets where price-competition is particularly harsh.

Our interpretation seems to find support in the literature: the positive relation between uncertainty and R\&D behaviour is explained by a "caution effect" that leads to a reduction in 
the responsiveness of $R \& D$ to changes in business conditions when uncertainty is higher (Bloom, 2007; Bloom et al., 2007).

Also, our findings support the (robust) evidence on the persistence over time of R\&D activities (see also Cefis and Orsenigo, 2001): decisions to invest in R\&D belong to firms' structural, long-term strategies. R\&D projects are characterised by high sunk costs, long lags between decisions to invest and project completion and an intrinsic high level of uncertainty, particularly technical uncertainty (Pindyck, 1993). After all, when investing in basic research and in the first phases of applied research, returns to R\&D are not only highly uncertain but in most cases highly risky. Part of the demand uncertainty might therefore be already "incorporated" in the strategic horizon of firms' decisions and may even be considered an incentive to face uncertainty by competing in terms of product quality within markets that tend to compete on prices.

In contrast, and interestingly for the purpose of our analysis, our findings show that firms' perception of lack of demand has a strong and significant negative effect on $R \& D$ strategy. Forecasting low demand for new goods and services not only has a negative effect on the amount invested in $R \& D$ but also reduces the likelihood of engaging in $R \& D$ altogether. ${ }^{12}$ Although a general stagnation of demand may affect prices and therefore lead to a net increase in demand for cheaper innovative products (OECD, 2012), our results show that the negative effect is dominant. This might suggest that, rather than the uncertainty around the demand for a single product or for a specific portfolio of products, it is the general expectation on the macro-economic conditions that ultimately favour decisions to invest in R\&D.

\footnotetext{
${ }^{12}$ Even when considering the joint effect of the increase in lack and uncertainty of demand, as shown in Table $2 \mathrm{~A}$ in the appendix, it clearly emerges that the negative effect of the perceived lack of demand dominates over uncertainty, as the net effect is still negative.
} 
Although firms might well respond to prospects of falling profitability due to recessive macro-economic conditions by increasing their investments in R\&D (Antonelli, $1989)^{13}$, our results seem to support the view that R\&D investments tend in general to be procyclical (Barlevy, 2007), with times of recession and demand stagnancy or decrease being associated with a reduction of $R \& D$ investments, which would further exacerbate the cycle. Falling demand (or expectations of it) might make it more difficult for firms to capture rents from their $R \& D$ investments and therefore delay $R \& D$ projects, which are then undertaken during periods of higher demand and expected rates of return (Fabrizio and Tsolmon, 2014), very much in line with a Schmooklerian pattern.

The pro-cyclical nature of $\mathrm{R} \& \mathrm{D}$ investments is further supported by our findings: conditional on the propensity to engage in $\mathrm{R} \& \mathrm{D}$, we find that an increasing perception of lack of demand has a negative effect on the amount devoted to R\&D projects. During times of falling demand, firms seem to reorient their R\&D efforts towards short-term and low risk innovations with the consequent reduction of R\&D expenditures. These results support our conjecture that, especially in time of crisis, macro-policies that privilege austerity and therefore reduce aggregate demand not only affect firms expectations on production, but also on the more risky $\mathrm{R} \& \mathrm{D}$ investments. We will return to these considerations in the concluding section.

\section{< INSERT TABLE $7>$}

\footnotetext{
${ }^{13}$ It has been shown (Antonelli, 1989) that, within a failure-inducement model of R\&D expenditures, firms facing declining rates of profits have incentives to increase their R\&D expenditures as a coping strategy. This is in line with the idea of innovation as being counter-cyclical to profitability losses due to falling demand put forward by Mensch (1975) (see also the works of Kleinknecht $(1984,1987)$ and Kleinknecht and Verspagen (1990). It would be interesting to test whether the behaviour of profits might influence the relationship between demand conditions and R\&D decisions, although from our results we suspect that the declining profitability due to a macro-economic recessive context is likely to reduce internal cash flows to fund $R \& D$ investments. Unfortunately, the data at our disposal do not include variables on profits.
} 


\section{< INSERT TABLES 8 AND 9 >}

\subsubsection{Control variables and robustness checks}

The results for the control variables present the expected signs and significance. First, both R\&D decisions (whether or not to invest and how much to invest) appear to be highly persistent over time as the parameters for the initial value and the lagged dependent variables are positive and highly significant. Second, in both estimations, the traditional firm characteristics affecting decisions related to $R \& D$ expenditures present the expected sign. Larger firms that conduct business internationally are more likely to carry out R\&D activities and to devote more resources to them. Moreover, although the literature is not unanimous on this point, our results suggest that there is a negative and significant relationship between age and $R \& D$, so that younger firms are more likely to carry out $R \& D$ activities. Third, other variables that characterise the innovation behaviour of firms, including the use of intellectual property rights and being recipients of public subsidies, also have a positive effect on $R \& D$ investments. Finally, while firms with higher levels of sales growth are more likely to engage in $\mathrm{R} \& \mathrm{D}$ and to invest more in $\mathrm{R} \& \mathrm{D}$, the increase in the perception of other obstacles to innovation exerts, in three out of four cases, an expected negative and highly significant effect on both decisions taken by the firm. These results are consistent with recent empirical analyses that underline the importance that size, international competition, subsidies and the growth of sales have, among other factors, on R\&D decisions and effort (Griffith et al., 2006; Artés, 2009; Garcia-Quevedo et al., 2014). In addition, our results are in line with some recent works that have emphasized the role of obstacles to innovation in explaining $R \& D$ activity and performance (Pellegrino and Savona, 2013) and productivity performance (Coad et al., 2015). 
The results of the estimations (Tables 8 and 9) are also consistent with most of the previous results regarding the effect and significance of the control variables across the four groups of sectors. The parameters for the initial conditions and the lagged dependent variables are positive and significant showing that the likelihood of carrying out $R \& D$ and R\&D investment are highly persistent across different sectors. In addition, as in the estimation for the full sample, size and participation in foreign markets show a positive relationship with the decision to engage in R\&D and the level of investment. Public subsidies also show positive and significant parameters across the four groups of sectors. On the other hand, age is only significant in the two services groups, showing a negative link as in the fullsample estimation. Moreover, the negative effect of the variable controlling for other obstacles is particularly important in knowledge-intensive sectors and in high and mediumhigh technology manufacturing sectors.

Finally, the magnitude and level of significance of the extra parameters reported at the bottom of tables 7,8 and 9 provide robust evidence that strongly support the adoption of the dynamic type-2 tobit model. Indeed, the two distinct equations (whether to engage in R\&D activity or not, and the conditional decision on how much to invest in R\&D) appear to be highly correlated via the individual effects and the cross-equation correlation. Furthermore, and very important, the high level of significance of the coefficients $\sigma_{u_{1}}$ and $\sigma_{u_{2}}$ indicates the need to take the unobserved heterogeneity into account.

\section{Concluding remarks}

This paper has revisited demand-pull perspectives within the innovation literature from the point of view of barriers to innovation. We have investigated whether perceptions of a lack of demand and demand uncertainty affect the propensity to invest in $R \& D$ and the intensity of the financial effort devoted to this activity. 
Our main conjecture is that expectations regarding profitability linked to stagnancy and uncertainty of demand are likely to affect strategic decisions on R\&D investments that go beyond the intrinsic uncertainty, high risk, irreversibility that characterise $R \& D$ investments. Dim prospects for the macro-economic conditions and the dynamics of demand might represent more of a deterrent for firms to even engage in $R \& D$ investments, whereas uncertainty regarding the product- and service-specific demand and user needs, while still being a deterrent, are likely to be incorporated in the firms' specific R\&D strategy.

We have found support to this conjecture. From our analysis it emerges that while the perception of an increasing lack of demand has a significant, strong and negative effect on both the decision to invest and the amount of investment in $R \& D$, increasing demand uncertainty does not seem to have any significant effect or to have a weakly significant positive effect, in line with other contributions (Stein and Stone, 2013).

This latter result turns out to be confined to the sector of low and medium/low-tech manufacturing industries. We have interpreted this result to be due to a specific response of low and medium low tech firms to higher uncertainty: a defensive strategy (or "caution effect") that might lead firms that traditionally operate in markets where price-competition is particularly harsh, to compete on product quality.

Overall, part of the demand uncertainty might therefore be already incorporated in the strategic horizon of firms' decisions when they engage in an intrinsically risky and uncertain activity such as R\&D.

Importantly, our results provide substantial support to the pro-cyclical nature of $R \& D$ investments. Most especially in time of crisis, macro-policies that privilege austerity and therefore reduce aggregate demand not only affect firms expectations on production, but also on the more risky R\&D investments. This might further exacerbate - although perhaps in the longer term - the effects of the crisis (Filippetti and Archibugi, 2011). 
These findings add to the debate on demand-pull and technology-push approaches in innovation studies from the novel perspective of barriers to innovation.

The literature on barriers is growing in importance, due to its obvious policy relevance. However, much of the scholarship produced to date, with few exceptions, has focused on financial barriers, overlooking other important hindrances that firms might face when deciding to innovate. Overlooking demand-related obstacles - we have argued and empirically shown - reflects the traditional dominance of technology-push perspectives and the way the debate between demand-pull and technology-push has been shaped over time (see Di Stefano et al., 2012 for a review).

An exhaustive consideration of the policy implications of these findings goes beyond the scope of this paper. However, our results support the importance of demand as an incentive to innovate and the need to foster demand-side innovation policies in the innovation policy agenda (Archibugi and Filippetti, 2011). Although the role of demand is still incipient in innovation policies (Edler and Georghiu, 2007), recent trends show an increase in, and a growing emphasis on, the use of demand-side innovation measures (OECD, 2011; Edler, 2013). For instance, public procurement for innovation is considered a powerful demand-side policy instrument (Edquist and Zabala-Iturriagagoitia, 2012). Innovative public procurement may impact positively on the size of demand and degree of sophistication that, as the demand-pull literature suggests, are two important factors to stimulate the innovative behaviour of firms (Raiteri, 2015; Guerzoni and Raiteri, 2015) and raise the general expectations on the ability of markets to absorb sophisticated products (see also discussion on the "competent demand-pull" (Antonelli and Gehringer, 2012) in Section 2). These measures may help guarantee markets for new goods and services and complement supply-side innovation policy tools. 


\section{References}

Aghion, P., Askenazy, P., Berman, N., Cette, G., Eymard, L., 2012. Credit Constraints and the Cyclicality of R\&D Investment: Evidence from France. Journal of the European Economic Association 10, 1001-1024.

Amemiya, Takeshi. 'Tobit Models: A Survey'. Journal of Econometrics 24, no. 1-2 (1984): 3-61.

Antonelli, C., 1989. A failure-inducement model of Research and Development expenditure. Journal of Economic Behavior and Organization 12, 159-180.

Antonelli, C., Gehringer, A. (2015). The competent demand pull hypothesis: which sectors do play a role? Economia Politica 32, 97-134.

Archibugi, D., Filippetti, A., 2011. Innovation and Economic Crisis: Lessons and Prospects from the Economic Downturn. Routledge.

Archibugi, D., Iammarino, S., 1999. The Policy Implications of the Globalisation of Innovation. Research Policy 28, 317-336.

Artés, J., 2009. Long-run versus short-run decisions, R\&D and market structure in Spanish firms. Research Policy 38, 120-132.

Atkinson, A.B., Stiglitz, J.E., 1969. A New View of Technological Change. The Economic Journal 79, 573-578.

Barlevy, G. 2007. On the Cyclicality of Research and Development, The American Economic Review 97, 1131-1164.

Blanchard, P., Huiban, J.-P., Musolesi, A., Sevestre, P., 2013. Where There Is a Will, There Is a Way? Assessing the Impact of Obstacles to Innovation. Industrial and Corporate Change 22, 679-710.

Bloom, N., 2007. Uncertainty and the Dynamics of R\&D. American Economic Review 97, 250-255.

Bloom, N., Bond, S., Reenen, J.V., 2007. Uncertainty and Investment Dynamics. Review of Economic Studies 74, 391-415.

Bond, S., Harhoff, D., Harho, D., Reenen, J.V., 1999. Investment, R\&D and Financial Constraints in Britain and Germany. Institute for Fiscal Studies.

Cainelli, G., Evangelista, R., Savona, M., 2006. Innovation and economic performance in services: a firm-level analysis, Cambridge Journal of Economics, 30, 435-58. 
Callejon, M., García-Quevedo, J., 2005. Public Subsidies to Business R\&D: Do they Stimulate Private Expenditures? Environment and Planning C: Government and Policy 23, 279-293.

Canepa, A., Stoneman, P., 2008. Financial Constraints to Innovation in the UK: Evidence from CIS2 and CIS3. Oxford Economic Papers 60, 711-730.

Cassiman, B., Golovko, E., Martínez-Ros, E., 2010. Innovation, Exports and Productivity. International Journal of Industrial Organization 28, 372-376.

Cefis, E., Orsenigo, L., 2001. The persistence of innovative activities: A cross-countries and cross-sectors comparative analysis. Research Policy 30, 1139-1158.

Clerides, S.K., Lach, S., Tybout, J.R., 1998. Is learning by exporting important? Microdynamic evidence from Colombia, Mexico and Morocco. Quarterly Journal of Economics 113, 903-947.

Coad, A., Pellegrino, G., Savona, M., 2015. Barriers to innovation and firm productivity. Economics of Innovation and New Technology, in press.

Czarnitzki, D., Toole, A.A., 2011. Patent Protection, Market Uncertainty, and R\&D Investment. Review of Economics and Statistics 93, 147-159.

Czarnitzki, D., Toole, A.A., 2013. The R\&D Investment-Uncertainty Relationship: Do Strategic Rivalry and Firm Size Matter? Managerial and Decision Economics 34, 15-28.

D’Este, P., Iammarino, S., Savona, M., von Tunzelmann, N., 2008. What Hampers Innovation? Evidence from UK CIS4 SPRU Electronic Working Paper Series (SEWPS), no. 168 (February).

D’Este, P., Iammarino, S., Savona, M., von Tunzelmann, N., 2012. What Hampers Innovation? Revealed Barriers Versus Deterring Barriers. Research Policy 41, 482-488.

D'Este, P., Rentocchini, F., Vega-Jurado, J., 2014. The Role of Human Capital in Lowering the Barriers to Engaging in Innovation: Evidence from the Spanish Innovation Survey. Industry \& Innovation 21, 1-19.

David, P.A., 1985. Clio and the Economics of QWERTY. The American Economic Review 75, 332-337.

Di Stefano, G., Gambardella, A., Verona, G., 2012. Technology push and demand pull perspectives in innovation studies: Current findings and future research directions. Research Policy 41, 1283-1295.

Dosi, G., 1982. Technological paradigms and technological trajectories: A suggested interpretation of the determinants and directions of technical change. Research Policy 11, $147-162$. 
Dosi, G., 1988. Sources, Procedures, and Microeconomic Effects of Innovation. Journal of Economic Literature 26, 1120-1171.

Edler, J., 2013. Review of Policy Measures to Stimulate Private Demand for Innovation. Concepts and Effects, Manchester Institute of Innovation Research, University of Manchester, January 2013 (http://research.mbs,ac.uk/innovation/).

Edler, J., Georghiu, L. 2007. Public procurement and innovation. Resurrecting the demand side. Research Policy 36, 949-963.

Edquist, C., Zabala-Iturriagagoitia, J.M., 2012. Public Procurement for Innovation as mission-oriented innovation policy. Research Policy 41, 1757-1769.

Fabrizio, K.R., Tsolmon, U. 2014. An empirical examination of the procyclicality of R\&D investement and innovation, Review of Economics and Statistics 96, 662-675.

Filippetti, A., Archibugi, D. 2011. Innovation in times of crisis: National Systems of Innovation, structure and demand. Research Policy 40(2), 179-192.

Fontana, R., Guerzoni, M., 2008. Incentives and uncertainty: an empirical analysis of the impact of demand on innovation. Cambridge Journal of Economics 32, 927-946.

Galende, J., de la Fuente, J.M., 2003. Internal Factors Determining a Firm's Innovative Behaviour. Research Policy 32, 715-736.

Gallouj, F., Savona, M., 2009. Innovation in services: a review of the debate and a research agenda. Journal of Evolutionary Economics 19, 149-172.

García Delgado, J.L., Myro, R., 2014. The Spanish Economy, Ed. Thomson-Reuters (Civitas), Spain.

García-Quevedo, J., Pellegrino, G., Vivarelli, M., 2014. R\&D drivers and age? Are young firms different? Research Policy 43, 1544-1556.

González, X., Jaumandreu, J., Pazó, C., 2005. Barriers to Innovation and Subsidy Effectiveness. The RAND Journal of Economics 36, 930-950.

Griffith, R., Huergo, E., Mairesse, J., Peters, B., 2006. Innovation and productivity across four European Countries. Oxford Review of Economic Policy 22, 483-498.

Guerzoni, M., Raiteri, E., 2015. Demand-side vs. supply-side technology policies: Hidden treatment and new empirical evidence on the policy mix. Research Policy 44, 726747.

Hall, B.H., 2002. The Financing of Research and Development. Oxford Review of Economic Policy 18, 35-51. 
Hall, B.H., Moncada-Paternò-Castello, P, Montresor, S., Vezzani, A. (2015). Financing constraints, R\&D investments and innovative performances: new empirical evidence at the firm level for Europe. Economics of Innovation and New Technology, in press.

Hottenrott, H., Peters, B., 2012. Innovative Capability and Financing Constraints for Innovation: More Money, More Innovation? Review of Economics and Statistics 94, 11261142 .

Iammarino, S., Sanna-Randaccio, R., Savona, M., 2009. The Perception of Obstacles to Innovation. Foreign Multinationals and Domestic Firms in Italy. Revue d'économie industrielle 125, 75-104.

Kleinknecht, A. 1984. Prosperity, crisis and innovation patterns, Cambridge Journal of Economics 8, 251-70.

Kleinknecht, A. 1987. Innovation Patterns in Crisis and Prosperity, London, Macmillan.

Kleinknecht, A., Verspagen, B., 1990. Demand and Innovation: Schmookler Reexamined. Research Policy 19, 387-394.

Klepper, S., 1996. Entry, Exit, Growth, and Innovation over the Product Life Cycle. The American Economic Review 86, 562-583.

Levin, R.C., Klevorick, A.K., Nelson, R.R., Winter, S.G., Gilbert, R., 1987. Appropriating the Returns from Industrial Research and Development. Brookings Papers on Economic Activity 3, 783-831.

Liu, X., Buck, T., 2007. Innovation Performance and Channels for International Technology Spillovers: Evidence from Chinese High-tech Industries. Research Policy 36, $355-366$.

López-García, P., Montero, J.M., Moral-Benito, E., 2013. Business Cycles and Investment in Productivity-Enhancing Activities: Evidence from Spanish Firms. Industry \& Innovation 20, 611-636.

Mairesse, J., Mohnen, P., 2002. Accounting for Innovation and Measuring Innovativeness: An Illustrative Framework and an Application. The American Economic Review 92, 226-230.

Mancusi, M.L., Vezzulli, A., 2010. R\&D, Innovation, and Liquidity Constraints. KITeS Working Papers 30/2010, Bocconi University.

Mensch, G. O. 1975. Stalemate in Technology, Cambridge, MA, Ballinger

Meyers, S., Marquis, D.G., 1969. Successful industrial innovation: critical factors for the 1990s. National Science Foundation, Washington, DC. 
Mowery, D., Rosenberg, N., 1979. The Influence of Market Demand Upon Innovation: a Critical Review of some Recent Empirical Studies. Research Policy 8, 102-153.

Mundlak, Y., 1978. On the Pooling of Time Series and Cross Section Data. Econometrica $46,69-85$.

Narula, R., Zanfei, A., 2003. The International Dimension of Innovation, in: Fagerberg, J., Mowery, D.C., Nelson, R.R. (Eds.), The Oxford Handbook of Innovation. Oxford University Press, Oxford, pp. 318-345.

OECD, 2011. Demand-side Innovation Policies. Organisation for Economic Cooperation and Development.

OECD, 2012. Innovation in the crisis and beyond, in: OECD Science, Technology and Industry Outlook. Organisation for Economic Co-operation and Development.

Pellegrino, G., Savona, M., 2013. Is money all? Financing versus knowledge and demand constraints to innovation. UNU-MERIT Working Paper Series 029.

Pindyck, R. 1993. Investments of uncertain cost. Journal of Financial Economics 34, 5376.

Piva, M., Vivarelli, M., 2007. Is Demand-pulled Innovation Equally Important in Different Groups of Firms? Cambridge Journal of Economics 31, 691-710.

Raiteri, E. (2015). A time to nourish? Evaluating the impact of innovative public procurement on technological generality through patent data. Cahiers du GREThA, 2015-05.

Raymond, W., Mohnen, P., Palm, F., van der Loeff, S.S., 2010. Persistence of Innovation in Dutch Manufacturing: Is It Spurious? Review of Economics and Statistics 92, 495-504.

Salomon, R.M., Shaver, J.M., 2005. Learning by Exporting: New Insights from Examining Firm Innovation. Journal of Economics \& Management Strategy 14, 431-460.

Savignac, F., 2008. Impact of Financial Constraints on Innovation: What Can Be Learned from a Direct Measure? Economics of Innovation and New Technology 17, 553-569.

Schiantarelli, F., 1996. Financial Constraints and Investment: Methodological Issues and International Evidence. Oxford Review of Economic Policy 12, 70-89.

Schmookler, J., 1962. Economic Sources of Inventive Activity. The Journal of Economic History 22, 1-20.

Schmookler, J., 1966. Invention and Economic Growth. Harvard University Press, MA.

Segarra, A., Teruel, M., 2014. High-growth firms and innovation: an empirical analysis for Spanish firms. Small Business Economics 1-17. 
Stein, L., Stone, E. 2013. The effect of uncertainty on investment, hiring and R\&D: Causal evidence from equity options, mineo.

Tiwari, A., Mohnen, P., Palm, F., Schim van der Loeff, S., 2008. Financial Constraint and R\&D Investment: Evidence from CIS, in: Determinants of Innovative Behaviours: A Firm's Internal Practice and Its External Environments. London, pp. 217-242.

Von Hippel, E., 1978. Successful Industrial Products from Customer Ideas. Journal of Marketing 42, 39.

Von Hippel, E., 1982. Appropriability of innovation benefit as a predictor of the source of innovation. Research Policy 11, 95-115.

Von Tunzelmann, N., Wang, Q., 2003. An Evolutionary View of Dynamic Capabilities. Structural Change and Economic Dynamics 6, 33-64.

Wallsten, S.J., 2000. The Effects of Government-Industry R\&D Programs on Private R\&D: The Case of the Small Business Innovation Research Program. The RAND Journal of Economics 31, 82-100.

Wooldridge, J.M., 2005. Simple Solutions to the Initial Conditions Problem in Dynamic, Nonlinear Panel Data Models with Unobserved Heterogeneity. Journal of Applied Econometrics 20, 39-54. 
Table 1. Composition of the panel

\begin{tabular}{ccccc}
\hline Time obs. & $\mathrm{N}^{\circ}$ of firms & $\%$ & $\%$ Cum & $\mathrm{N}^{\circ}$ of obs. \\
\hline 2 & 384 & 4.26 & 4.26 & 768 \\
3 & 511 & 5.55 & 9.81 & 1,533 \\
4 & 647 & 7.08 & 16.89 & 2,588 \\
5 & 893 & 9.85 & 26.74 & 4,465 \\
6 & 2,123 & 23.25 & 49.99 & 12,738 \\
7 & 4,574 & 50.01 & 100.00 & 32,018 \\
\hline Total & 9,132 & 100 & & 54,110 \\
\hline
\end{tabular}

Note: the final sample only comprises firms for which a lag of the dependent variable is available. This implies that $\mathrm{t}=2$ refers to firms that are observed for at least three periods, $t=3$ corresponds to firms that are observed for four periods and so on.

Table 2. Transition probabilities: $R \& D$ performers

\begin{tabular}{|c|c|c|c|}
\hline \multirow{6}{*}{ 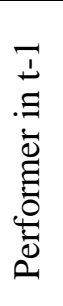 } & & \multicolumn{2}{|c|}{ Performer in $\mathrm{t}$} \\
\hline & & \multicolumn{2}{|c|}{ R\&D } \\
\hline & & 0 & 1 \\
\hline & 0 & 90.95 & 9.05 \\
\hline & 1 & 14.15 & 85.85 \\
\hline & Total & 43.98 & 56.02 \\
\hline
\end{tabular}


Table 3. Sectoral composition for macro categories (relative frequencies) and percentage of firms that experienced an increase in the degree of importance of the demand (uncertainty and lack) related obstacles

\begin{tabular}{|c|c|c|c|c|c|c|}
\hline & $\begin{array}{l}\text { Freq. For } \\
\text { category }\end{array}$ & $\begin{array}{l}\% \text { over } \\
\text { category }\end{array}$ & $\begin{array}{c}\% \text { over } \\
\text { total }\end{array}$ & $\begin{array}{c}\text { Employment } \\
(\%)\end{array}$ & $\begin{array}{c}\text { Incr. in lack } \\
\text { of demand }\end{array}$ & $\begin{array}{l}\text { Incr. in } \\
\text { uncertainty } \\
\text { demand }\end{array}$ \\
\hline Low/Med-Low & 18,730 & 100.00 & 34.61 & 18.13 & 16.27 & 19.87 \\
\hline Petroleum & 39 & 0.21 & 0.07 & 0.85 & 10.26 & 20.51 \\
\hline Food products beverages, tobacco & 4,109 & 21.94 & 7.59 & 5.10 & 16.50 & 19.96 \\
\hline Textiles & 1,180 & 6.30 & 2.18 & 0.65 & 13.90 & 16.86 \\
\hline Wearing apparel & 370 & 1.98 & 0.68 & 0.66 & 14.32 & 24.32 \\
\hline Leather -products, footwear & 359 & 1.91 & 0.66 & 0.19 & 19.50 & 18.38 \\
\hline Wood-products, cork & 599 & 3.20 & 1.11 & 0.43 & 20.03 & 24.71 \\
\hline Pulp/paper-products & 546 & 2.92 & 1.01 & 0.77 & 13.00 & 16.12 \\
\hline Rubber and plastics & 1,981 & 10.57 & 3.66 & 1.85 & 14.89 & 19.59 \\
\hline Mineral products (no metallic) & 1,736 & 9.27 & 3.21 & 1.78 & 17.40 & 20.68 \\
\hline Basic metals & 955 & 5.10 & 1.76 & 1.61 & 16.65 & 20.52 \\
\hline Fabricated metal products & 3,464 & 18.49 & 6.40 & 2.19 & 17.26 & 20.84 \\
\hline Furniture & 1,119 & 5.98 & 2.07 & 0.81 & 18.77 & 21.00 \\
\hline Other manufacturing n.e.c. & 1,835 & 9.80 & 3.39 & 0.75 & 14.39 & 18.37 \\
\hline Repair of fabricated metal products & 438 & 2.34 & 0.81 & 0.50 & 13.47 & 19.86 \\
\hline High/Med-High & 11,736 & 100.00 & 21.69 & 14.23 & 13.54 & 17.39 \\
\hline Chemicals & 3,364 & 28.67 & 6.22 & 2.26 & 12.90 & 16.59 \\
\hline Pharmaceutical & 909 & 7.75 & 1.68 & 1.52 & 10.34 & 16.50 \\
\hline Electronic, optical, computer products & 1,049 & 8.94 & 1.94 & 0.80 & 12.96 & 17.35 \\
\hline Electrical equipment & 1,265 & 10.77 & 2.34 & 1.51 & 13.20 & 18.02 \\
\hline Other machinery & 3,540 & 30.17 & 6.54 & 2.29 & 15.31 & 17.91 \\
\hline Motor vehicles & 1,274 & 10.86 & 2.35 & 4.78 & 13.19 & 18.29 \\
\hline Aerospace & 143 & 1.21 & 0.26 & 0.53 & 13.29 & 15.38 \\
\hline Other transport equipment & 192 & 1.64 & 0.35 & 0.54 & 15.10 & 17.71 \\
\hline KIS & 11,942 & 100.00 & 22.07 & 19.45 & 15.26 & 19.58 \\
\hline Telecommunications & 312 & 2.61 & 0.58 & 1.48 & 13.46 & 22.12 \\
\hline Computer programming activities & 4,207 & 35.24 & 7.77 & 3.05 & 15.43 & 20.25 \\
\hline Other inform. and communication serv. & 951 & 7.96 & 1.76 & 0.85 & 18.30 & 22.08 \\
\hline Financial intermediation, insurance & 1,086 & 9.09 & 2.01 & 9.93 & 15.29 & 17.03 \\
\hline Research and development services & 1,678 & 14.05 & 3.10 & 0.70 & 11.98 & 17.10 \\
\hline Other activities* & 3,505 & 29.34 & 6.48 & 3.35 & 19.60 & 19.80 \\
\hline Education & 203 & 1.70 & 0.38 & 0.09 & 15.76 & 20.20 \\
\hline LKIS & 11,702 & 100.00 & 21.63 & 48.19 & 17.90 & 22.26 \\
\hline Trade & 4,236 & 36.20 & 7.83 & 15.70 & 16.34 & 20.87 \\
\hline Passenger transport, warehousing & 1,153 & 9.86 & 2.13 & 8.01 & 20.29 & 23.42 \\
\hline Hotels and Restaurants & 708 & 6.04 & 1.31 & 3.43 & 17.37 & 23.73 \\
\hline Real Estate & 317 & 2.71 & 0.59 & 0.54 & 19.87 & 22.71 \\
\hline Public administration and auxiliary serv. & 3,186 & 27.22 & 5.89 & 14.52 & 17.92 & 23.07 \\
\hline Other service activities $* *$ & 2,102 & 17.97 & 3.88 & 5.98 & 8.52 & 22.65 \\
\hline TOTAL & 54,110 & & 100.00 & 100.00 & 15.81 & 19.78 \\
\hline
\end{tabular}


Table 4. Percentage of firms that report an increase in the degree of importance of the demand (uncertainty and lack) related obstacles. (by year and sectoral categories)

\begin{tabular}{lcccccccccccccc}
\hline & \multicolumn{2}{c}{2005} & \multicolumn{2}{c}{2006} & \multicolumn{2}{c}{2007} & \multicolumn{2}{c}{2008} & \multicolumn{2}{c}{2009} & \multicolumn{2}{c}{2010} & \multicolumn{2}{c}{2011} \\
& Un. & Lack & Un. & Lack & Un. & Lack & Un. & Lack & Un. & Lack & Un. & Lack & Un. & Lack \\
& Dem. & Dem. & Dem. & Dem. & Dem. & Dem. & Dem. & Dem. & Dem. & Dem. & Dem. & Dem. & Dem. & Dem. \\
\hline Low/Med-Low & 24.07 & 18.80 & 19.92 & 16.80 & 19.14 & 13.91 & 20.50 & 17.25 & 19.15 & 15.33 & 18.58 & 16.73 & 17.98 & 15.44 \\
High/Med-High & 20.00 & 16.91 & 17.69 & 13.32 & 17.00 & 11.98 & 18.07 & 14.23 & 16.90 & 11.54 & 16.79 & 13.88 & 15.25 & 13.38 \\
KIS & 24.37 & 17.76 & 20.86 & 15.47 & 19.17 & 14.59 & 19.96 & 16.27 & 17.74 & 15.45 & 17.36 & 14.23 & 18.38 & 13.27 \\
LKIS & 26.57 & 20.28 & 23.52 & 20.57 & 20.37 & 15.28 & 25.11 & 18.16 & 20.36 & 17.86 & 19.87 & 16.54 & 20.43 & 16.88 \\
\hline Total & 23.73 & 18.47 & 20.40 & 16.54 & 18.95 & 13.94 & 20.87 & 16.59 & 18.61 & 15.09 & 18.21 & 15.51 & 18.03 & 14.84 \\
Observations & 6,616 & 8,524 & 8,439 & 8,229 & 7,931 & 7,459 & 6,912 \\
\hline
\end{tabular}

Table 5. Descriptive statistics: mean and standard deviation of the variables; all firms and 4 sectoral categories

\begin{tabular}{lccccccccccc}
\hline & \multicolumn{3}{c}{ All firms } & \multicolumn{3}{c}{ Low/Med-low } & \multicolumn{2}{c}{ High/Med-high } & \multicolumn{2}{c}{ Kis } & \multicolumn{2}{c}{ Lkis } \\
& Mean & Sd & Mean & Sd & Mean & Sd & Mean & Sd & Mean & Sd \\
\hline $\ln ($ R\&D) & 7.20 & 6.21 & 6.92 & 6.05 & 9.62 & 5.52 & 8.43 & 6.17 & 3.95 & 5.67 \\
R\&D dummy & 0.58 & 0.49 & 0.58 & 0.49 & 0.77 & 0.42 & 0.66 & 0.47 & 0.33 & 0.47 \\
R\&D dummy t-1 & 0.63 & 0.48 & 0.63 & 0.48 & 0.80 & 0.40 & 0.70 & 0.46 & 0.37 & 0.48 \\
Lack of demand & 0.16 & 0.36 & 0.16 & 0.37 & 0.14 & 0.34 & 0.15 & 0.36 & 0.18 & 0.38 \\
Uncertainty & 0.20 & 0.40 & 0.20 & 0.40 & 0.17 & 0.38 & 0.20 & 0.40 & 0.22 & 0.42 \\
ln(Age) & 3.06 & 0.65 & 3.19 & 0.62 & 3.20 & 0.63 & 2.77 & 0.66 & 3.02 & 0.61 \\
Exporter dummy t-1 & 0.63 & 0.48 & 0.77 & 0.42 & 0.85 & 0.36 & 0.43 & 0.50 & 0.37 & 0.48 \\
Industrial group & 0.37 & 0.48 & 0.34 & 0.47 & 0.42 & 0.49 & 0.35 & 0.48 & 0.39 & 0.49 \\
Patent dummy t-1 & 0.13 & 0.33 & 0.13 & 0.33 & 0.20 & 0.40 & 0.13 & 0.33 & 0.05 & 0.22 \\
Informal protection dummy t-1 & 0.24 & 0.43 & 0.25 & 0.44 & 0.27 & 0.44 & 0.26 & 0.44 & 0.18 & 0.38 \\
ln(Size) & 4.10 & 1.56 & 4.05 & 1.29 & 4.08 & 1.34 & 3.66 & 1.67 & 4.65 & 1.87 \\
Subsidy dummy t-1 & 0.37 & 0.48 & 0.35 & 0.48 & 0.42 & 0.49 & 0.48 & 0.50 & 0.22 & 0.42 \\
Sales growth & 0.00 & 0.59 & -0.01 & 0.42 & 0.00 & 0.51 & 0.02 & 0.78 & 0.00 & 0.66 \\
Other obstacles & 0.47 & 0.50 & 0.48 & 0.50 & 0.45 & 0.50 & 0.47 & 0.50 & 0.46 & 0.50 \\
\hline Observation & 54,110 & 18,730 & & 11,736 & & 11,942 & 11,702 \\
\hline
\end{tabular}


Table 6. Descriptive statistics: mean of the variables by sectoral categories and by obstacles variables status (whole sample, LMLt, HMHt)

\begin{tabular}{|c|c|c|c|c|c|c|c|c|c|c|c|c|}
\hline & \multicolumn{5}{|c|}{ Whole sample } & \multicolumn{4}{|c|}{ Low/Med-low } & \multicolumn{3}{|c|}{ High/Med-high } \\
\hline & $\begin{array}{l}\text { No- } \\
\text { obst. }\end{array}$ & $\begin{array}{l}\text { Uncer. } \\
\text { Dem. }\end{array}$ & $\begin{array}{c}\text { Lack of } \\
\text { Dem. }\end{array}$ & $\begin{array}{l}\text { Both } \\
\text { Obst }\end{array}$ & $\begin{array}{l}\text { No- } \\
\text { obst. }\end{array}$ & $\begin{array}{c}\text { Uncer. } \\
\text { Dem. }\end{array}$ & $\begin{array}{c}\text { Lack } \\
\text { of } \\
\text { Dem. }\end{array}$ & $\begin{array}{l}\text { Both } \\
\text { Obst }\end{array}$ & $\begin{array}{l}\text { No- } \\
\text { obst. }\end{array}$ & $\begin{array}{c}\text { Uncer. } \\
\text { Dem. }\end{array}$ & $\begin{array}{c}\text { Lack } \\
\text { of } \\
\text { Dem. } \\
\end{array}$ & $\begin{array}{l}\text { Both } \\
\text { Obst }\end{array}$ \\
\hline $\ln (\mathrm{R} \& \mathrm{D})$ & 7.65 & 6.87 & 5.34 & 5.57 & 7.36 & 6.70 & 5.11 & 5.37 & 10.01 & 9.35 & 7.43 & 8.15 \\
\hline R\&D dummy & 0.62 & 0.56 & 0.44 & 0.46 & 0.61 & 0.55 & 0.43 & 0.46 & 0.79 & 0.74 & 0.61 & 0.67 \\
\hline R\&D dummy t-1 & 0.65 & 0.58 & 0.56 & 0.54 & 0.65 & 0.58 & 0.57 & 0.55 & 0.82 & 0.77 & 0.73 & 0.73 \\
\hline $\ln ($ Age $)$ & 3.08 & 3.01 & 3.01 & 3.04 & 3.20 & 3.14 & 3.14 & 3.18 & 3.22 & 3.16 & 3.16 & 3.14 \\
\hline Lack of demand & 0 & 0 & 1 & 1 & 0 & 0 & 1 & 1 & 0 & 0 & 1 & 1 \\
\hline Uncertainty & 0 & 1 & 0 & 1 & 0 & 1 & 0 & 1 & 0 & 1 & 0 & 1 \\
\hline Exporter dummy t-1 & 0.65 & 0.59 & 0.58 & 0.56 & 0.78 & 0.74 & 0.73 & 0.70 & 0.86 & 0.83 & 0.82 & 0.78 \\
\hline Industrial group & 0.38 & 0.35 & 0.33 & 0.35 & 0.35 & 0.33 & 0.28 & 0.31 & 0.43 & 0.41 & 0.36 & 0.39 \\
\hline Patent dummy t-1 & 0.13 & 0.11 & 0.11 & 0.10 & 0.13 & 0.12 & 0.11 & 0.10 & 0.20 & 0.17 & 0.17 & 0.17 \\
\hline Informal protection dummy $\mathrm{t}-1$ & 0.25 & 0.22 & 0.22 & 0.20 & 0.26 & 0.24 & 0.23 & 0.22 & 0.28 & 0.25 & 0.23 & 0.24 \\
\hline $\ln ($ Size $)$ & 4.14 & 4.05 & 3.94 & 4.06 & 4.10 & 3.99 & 3.81 & 3.96 & 4.12 & 4.07 & 3.87 & 3.91 \\
\hline Subsidy dummy t-1 & 0.38 & 0.35 & 0.33 & 0.32 & 0.36 & 0.33 & 0.32 & 0.33 & 0.42 & 0.42 & 0.37 & 0.37 \\
\hline Sales growth & 0.00 & 0.01 & -0.03 & -0.01 & -0.01 & -0.01 & -0.05 & 0.00 & 0.01 & 0.01 & -0.02 & -0.03 \\
\hline Other obstacles & 0.40 & 0.60 & 0.74 & 0.54 & 0.41 & 0.61 & 0.74 & 0.54 & 0.39 & 0.64 & 0.73 & 0.51 \\
\hline Observation & 38,244 & 7,313 & 5,161 & 3,392 & 13,198 & 2,485 & 1,811 & 1,236 & 8,733 & 1,414 & 962 & 627 \\
\hline$\%$ & 70.68 & 13.52 & 9.54 & 6.27 & 70.46 & 13.27 & 9.67 & 6.60 & 74.41 & 12.05 & 8.20 & 5.34 \\
\hline
\end{tabular}


Table 6 (continued) - Descriptive statistics: mean of the variables by sectoral categories and by obstacles variables status (Kis and LKIS)

\begin{tabular}{|c|c|c|c|c|c|c|c|c|}
\hline & \multicolumn{4}{|c|}{ Kis } & \multicolumn{4}{|c|}{ Lkis } \\
\hline & No-obst. & $\begin{array}{c}\text { Uncer. } \\
\text { Dem. }\end{array}$ & $\begin{array}{c}\text { Lack of } \\
\text { Dem. }\end{array}$ & Both Obst & No-obst. & $\begin{array}{c}\text { Uncer. } \\
\text { Dem. }\end{array}$ & $\begin{array}{c}\text { Lack of } \\
\text { Dem. }\end{array}$ & Both Obst \\
\hline $\ln (\mathrm{R} \& \mathrm{D})$ & 8.77 & 8.40 & 6.84 & 6.94 & 4.31 & 3.75 & 2.80 & 2.73 \\
\hline R\&D dummy & 0.69 & 0.67 & 0.55 & 0.55 & 0.36 & 0.31 & 0.24 & 0.24 \\
\hline R\&D dummy t-1 & 0.72 & 0.70 & 0.65 & 0.62 & 0.39 & 0.32 & 0.35 & 0.33 \\
\hline $\ln ($ Age $)$ & 2.80 & 2.70 & 2.70 & 2.78 & 3.04 & 2.99 & 2.99 & 2.97 \\
\hline Lack of demand & 0 & 0 & 1 & 1 & 0 & 0 & 1 & 1 \\
\hline Uncertainty & 0 & 1 & 0 & 1 & 0 & 1 & 0 & 1 \\
\hline Exporter dummy t-1 & 0.45 & 0.41 & 0.39 & 0.38 & 0.39 & 0.34 & 0.34 & 0.34 \\
\hline Industrial group & 0.35 & 0.33 & 0.33 & 0.36 & 0.39 & 0.37 & 0.38 & 0.38 \\
\hline Patent dummy t-1 & 0.13 & 0.13 & 0.11 & 0.10 & 0.06 & 0.05 & 0.05 & 0.03 \\
\hline Informal protection dummy $\mathrm{t}-1$ & 0.26 & 0.25 & 0.24 & 0.20 & 0.19 & 0.15 & 0.17 & 0.15 \\
\hline $\ln (\operatorname{Size})$ & 3.71 & 3.53 & 3.50 & 3.67 & 4.67 & 4.62 & 4.56 & 4.65 \\
\hline Subsidy dummy t-1 & 0.49 & 0.48 & 0.43 & 0.39 & 0.23 & 0.21 & 0.20 & 0.19 \\
\hline Sales growth & 0.02 & 0.04 & -0.01 & -0.05 & 0.00 & 0.01 & -0.05 & 0.02 \\
\hline Other obstacles & 0.40 & 0.64 & 0.74 & 0.59 & 0.40 & 0.50 & 0.75 & 0.52 \\
\hline Observation & 8,491 & 1,629 & 1,113 & 709 & 7,822 & 1,785 & 1,275 & 820 \\
\hline$\%$ & 71.1 & 13.64 & 9.32 & 5.94 & 66.84 & 15.25 & 10.9 & 7.01 \\
\hline
\end{tabular}


Table 7. Dynamic type 2 tobit estimates (whole sample)

\begin{tabular}{|c|c|c|c|c|}
\hline & $\begin{array}{c}\text { (1) } \\
\text { R\&D Dummy }\end{array}$ & $\begin{array}{c}(2) \\
\operatorname{Ln}(\mathrm{R} \& \mathrm{D})\end{array}$ & $\begin{array}{c}\text { (3) } \\
\text { R\&D Dummy }\end{array}$ & $\begin{array}{c}(4) \\
\operatorname{Ln}(R \& D)\end{array}$ \\
\hline R\&D Dummy t-1 & $\begin{array}{c}1.743 * * * \\
(0.023)\end{array}$ & & $\begin{array}{c}1.762 * * * \\
(0.023)\end{array}$ & \\
\hline R\&D Dummy $t_{0}$ & $\begin{array}{c}0.970 * * * \\
(0.036)\end{array}$ & & $\begin{array}{c}0.943 * * * \\
(0.036)\end{array}$ & \\
\hline $\operatorname{Ln}(\mathrm{R} \& \mathrm{D}) \mathrm{t}-1$ & & $\begin{array}{c}0.115 * * * \\
(0.002)\end{array}$ & & $\begin{array}{c}0.115 * * * \\
(0.002)\end{array}$ \\
\hline $\operatorname{Ln}(\mathrm{R} \& D) \mathrm{t}_{0}$ & & $\begin{array}{c}0.093 * * * \\
(0.002)\end{array}$ & & $\begin{array}{c}0.092 * * * \\
(0.002)\end{array}$ \\
\hline Uncertainty & $\begin{array}{c}0.003 \\
(0.019)\end{array}$ & $\begin{array}{c}0.041 * * * \\
(0.014)\end{array}$ & & \\
\hline Lack of demand & & & $\begin{array}{c}-0.353^{* * *} * \\
(0.021)\end{array}$ & $\begin{array}{c}-0.170 * * * \\
(0.017)\end{array}$ \\
\hline $\ln ($ Age $)$ & $\begin{array}{c}-0.047 * * * \\
(0.017)\end{array}$ & $\begin{array}{c}-0.132 * * * \\
(0.014)\end{array}$ & $\begin{array}{c}-0.049 * * * \\
(0.017)\end{array}$ & $\begin{array}{c}-0.133^{* * * *} \\
(0.014)\end{array}$ \\
\hline Exporter dummy t-1 & $\begin{array}{c}0.279 * * * \\
(0.021)\end{array}$ & $\begin{array}{c}0.194 * * * \\
(0.017)\end{array}$ & $\begin{array}{c}0.272 * * * \\
(0.021)\end{array}$ & $\begin{array}{c}0.190 * * * \\
(0.017)\end{array}$ \\
\hline Industrial group & $\begin{array}{c}0.045^{* *} \\
(0.022)\end{array}$ & $\begin{array}{c}0.258 * * * \\
(0.018)\end{array}$ & $\begin{array}{c}0.045^{* *} \\
(0.022)\end{array}$ & $\begin{array}{c}0.259 * * * \\
(0.018)\end{array}$ \\
\hline Patent dummy $\mathrm{t}-1$ & $\begin{array}{c}0.218 * * * \\
(0.030)\end{array}$ & $\begin{array}{c}0.250 * * * \\
(0.018)\end{array}$ & $\begin{array}{c}0.219 * * * \\
(0.030)\end{array}$ & $\begin{array}{c}0.251 * * * \\
(0.018)\end{array}$ \\
\hline Informal protection dummy $\mathrm{t}-1$ & $\begin{array}{c}0.131 * * * \\
(0.022)\end{array}$ & $\begin{array}{c}0.055^{* * * *} \\
(0.015)\end{array}$ & $\begin{array}{c}0.126 * * * \\
(0.022)\end{array}$ & $\begin{array}{c}0.052 * * * \\
(0.015)\end{array}$ \\
\hline $\ln ($ Size $)$ & $\begin{array}{c}0.156^{* * * *} \\
(0.008)\end{array}$ & $\begin{array}{c}0.494 * * * \\
(0.006)\end{array}$ & $\begin{array}{c}0.154 * * * \\
(0.008)\end{array}$ & $\begin{array}{c}0.494 * * * \\
(0.006)\end{array}$ \\
\hline Subsidy dummy t-1 & $\begin{array}{c}0.273 * * * \\
(0.019)\end{array}$ & $\begin{array}{c}0.330 * * * \\
(0.014)\end{array}$ & $\begin{array}{c}0.271 * * * \\
(0.019)\end{array}$ & $\begin{array}{c}0.330 * * * \\
(0.014)\end{array}$ \\
\hline Sales growth & $\begin{array}{c}0.103 * * * \\
(0.014)\end{array}$ & $\begin{array}{c}0.038 * * * \\
(0.010)\end{array}$ & $\begin{array}{c}0.098 * * * \\
(0.014)\end{array}$ & $\begin{array}{c}0.037 * * * \\
(0.009)\end{array}$ \\
\hline Other obstacles & $\begin{array}{c}-0.119 * * * \\
(0.016)\end{array}$ & $\begin{array}{c}-0.028 * * \\
(0.011)\end{array}$ & $\begin{array}{c}-0.083^{* * *} * \\
(0.016)\end{array}$ & $\begin{array}{l}-0.009 \\
(0.011)\end{array}$ \\
\hline Constant & $\begin{array}{c}-2.521 * * * \\
(0.070) \\
\end{array}$ & $\begin{array}{c}7.369 * * * \\
(0.057) \\
\end{array}$ & $\begin{array}{c}-2.450 * * * \\
(0.069) \\
\end{array}$ & $\begin{array}{c}7.416 * * * \\
(0.056) \\
\end{array}$ \\
\hline $\mathrm{N}^{\circ}$ of observations & 54,110 & 31,558 & 54,110 & 31,558 \\
\hline$\rho_{\mathrm{u} 1 \mathrm{u} 2}$ & \multicolumn{2}{|c|}{$\begin{array}{c}0.306 * * * \\
(0.015)\end{array}$} & \multicolumn{2}{|c|}{$\begin{array}{c}0.309 * * * \\
(0.015)\end{array}$} \\
\hline$\rho_{\varepsilon 1 \varepsilon 2}$ & \multicolumn{2}{|c|}{$\begin{array}{c}0.707 * * * \\
(0.020)\end{array}$} & \multicolumn{2}{|c|}{$0.712 * * *$} \\
\hline$\sigma_{\mathrm{u} 1}$ & \multicolumn{2}{|c|}{$-0.637 * * *$} & \multicolumn{2}{|c|}{$\begin{array}{c}-0.609 * * * \\
(0.032)\end{array}$} \\
\hline$\sigma_{\mathrm{u} 2}$ & \multicolumn{2}{|c|}{$-0.303 * * *$} & \multicolumn{2}{|c|}{$-0.300 * * *$} \\
\hline$\sigma_{\varepsilon 2}$ & \multicolumn{2}{|c|}{$-0.079 * * *$} & \multicolumn{2}{|c|}{$\begin{array}{c}-0.078 * * * \\
(0.005)\end{array}$} \\
\hline
\end{tabular}

Notes; $* * * * *$ and $*$ indicate significance on a $1 \%, 5 \%$ and $10 \%$ level, respectively. Standard errors in brackets. Time and industry dummies are included. 
Table 8. Dynamic type 2 tobit estimates for Manufacturing sectors (Low/medium and High/medium tech sectors)

\begin{tabular}{|c|c|c|c|c|c|c|c|c|}
\hline & \multicolumn{4}{|c|}{ Low/medium-low tech Sectors } & \multicolumn{4}{|c|}{ High/medium-high tech Sectors } \\
\hline & $\begin{array}{c}(1) \\
\text { R\&D } \\
\text { Dummy }\end{array}$ & $\begin{array}{c}(2) \\
\operatorname{Ln}(\mathrm{R} \& \mathrm{D})\end{array}$ & $\begin{array}{c}(3) \\
\text { R\&D } \\
\text { Dummy }\end{array}$ & $\begin{array}{c}(4) \\
\operatorname{Ln}(\mathrm{R} \& \mathrm{D})\end{array}$ & $\begin{array}{c}(5) \\
\text { R\&D } \\
\text { Dummy }\end{array}$ & $\begin{array}{c}(6) \\
\mathrm{Ln} \\
(\mathrm{R} \& \mathrm{D}) \\
\end{array}$ & $\begin{array}{c}\text { (7) } \\
\text { R\&D } \\
\text { Dummy }\end{array}$ & $\begin{array}{c}\text { (8) } \\
\mathrm{Ln} \\
(\mathrm{R} \& \mathrm{D})\end{array}$ \\
\hline R\&D Dummy t-1 & $\begin{array}{c}1.740 * * * \\
(0.036)\end{array}$ & & $\begin{array}{c}1.720 * * * \\
(0.038)\end{array}$ & & $\begin{array}{c}1.940 * * * \\
(0.053)\end{array}$ & & $\begin{array}{l}1.900 * * * \\
(0.055)\end{array}$ & \\
\hline R\&D Dummy $t_{0}$ & $\begin{array}{c}0.774 * * * \\
(0.054)\end{array}$ & & $\begin{array}{c}0.800 * * * \\
(0.056)\end{array}$ & & $\begin{array}{c}0.919 * * * \\
(0.094)\end{array}$ & & $\begin{array}{c}0.961 * * * \\
(0.096)\end{array}$ & \\
\hline $\operatorname{Ln}(\mathrm{R} \& \mathrm{D}) \mathrm{t}-1$ & & $\begin{array}{c}0.110 * * * \\
(0.004)\end{array}$ & & $\begin{array}{c}0.107 * * * \\
(0.004)\end{array}$ & & $\begin{array}{c}0.113 * * * \\
(0.004)\end{array}$ & & $\begin{array}{c}0.109 * * * \\
(0.004)\end{array}$ \\
\hline $\operatorname{Ln}(\mathrm{R} \& \mathrm{D}) \mathrm{t}_{0}$ & & $\begin{array}{c}0.065 * * * \\
(0.004)\end{array}$ & & $\begin{array}{c}0.066^{* * *} * \\
(0.004)\end{array}$ & & $\begin{array}{c}0.096 * * * \\
(0.004)\end{array}$ & & $\begin{array}{c}0.097 * * * \\
(0.004)\end{array}$ \\
\hline Uncertainty & $\begin{array}{c}0.003 \\
(0.031)\end{array}$ & $\begin{array}{c}0.065 * * * \\
(0.024)\end{array}$ & & & $\begin{array}{c}0.005 \\
(0.045)\end{array}$ & $\begin{array}{c}0.011 \\
(0.025)\end{array}$ & & \\
\hline Lack of demand & & & $\begin{array}{c}-0.378 * * * \\
(0.034)\end{array}$ & $\begin{array}{c}-0.130 * * * \\
(0.028)\end{array}$ & & & $\begin{array}{c}-0.377 * * * \\
(0.048)\end{array}$ & $\begin{array}{c}-0.171 * * * \\
(0.029)\end{array}$ \\
\hline $\ln ($ Age $)$ & $\begin{array}{l}-0.019 \\
(0.026)\end{array}$ & $\begin{array}{l}-0.007 \\
(0.024)\end{array}$ & $\begin{array}{c}0.002 \\
(0.027)\end{array}$ & $\begin{array}{l}-0.045^{*} \\
(0.024)\end{array}$ & $\begin{array}{l}-0.028 \\
(0.037)\end{array}$ & $\begin{array}{c}-0.065 * * * \\
(0.022)\end{array}$ & $\begin{array}{c}0.002 \\
(0.038)\end{array}$ & $\begin{array}{c}-0.107 * * * \\
(0.023)\end{array}$ \\
\hline Exporter dummy t-1 & $\begin{array}{c}0.340 * * * \\
(0.036)\end{array}$ & $\begin{array}{c}0.213 * * * \\
(0.034)\end{array}$ & $\begin{array}{c}0.343 * * * \\
(0.037)\end{array}$ & $\begin{array}{c}0.195^{* * * *} \\
(0.034)\end{array}$ & $\begin{array}{c}0.252 * * * \\
(0.055)\end{array}$ & $\begin{array}{l}-0.006 \\
(0.037)\end{array}$ & $\begin{array}{c}0.257 * * * \\
(0.056)\end{array}$ & $\begin{array}{l}-0.017 \\
(0.037)\end{array}$ \\
\hline Industrial group & $\begin{array}{c}0.092 * * \\
(0.036)\end{array}$ & $\begin{array}{c}0.245 * * * \\
(0.030)\end{array}$ & $\begin{array}{c}0.110 * * * \\
(0.037)\end{array}$ & $\begin{array}{c}0.221 * * * \\
(0.030)\end{array}$ & $\begin{array}{l}-0.052 \\
(0.052)\end{array}$ & $\begin{array}{c}0.320 * * * \\
(0.032)\end{array}$ & $\begin{array}{l}-0.037 \\
(0.053)\end{array}$ & $\begin{array}{c}0.287 * * * \\
(0.032)\end{array}$ \\
\hline Patent dummy t-1 & $\begin{array}{c}0.215^{* * * *} \\
(0.046)\end{array}$ & $\begin{array}{c}0.157 * * * \\
(0.031)\end{array}$ & $\begin{array}{c}0.221 * * * \\
(0.047)\end{array}$ & $\begin{array}{c}0.168 * * * \\
(0.031)\end{array}$ & $\begin{array}{c}0.094 \\
(0.060)\end{array}$ & $\begin{array}{c}0.141 * * * \\
(0.028)\end{array}$ & $\begin{array}{l}0.105^{*} \\
(0.061)\end{array}$ & $\begin{array}{c}0.152 * * * \\
(0.028)\end{array}$ \\
\hline Informal prot. dummy $\mathrm{t}-1$ & $\begin{array}{c}0.139 * * * \\
(0.034)\end{array}$ & $\begin{array}{c}0.007 \\
(0.025)\end{array}$ & $\begin{array}{c}0.125 * * * \\
(0.035)\end{array}$ & $\begin{array}{c}0.015 \\
(0.025)\end{array}$ & $\begin{array}{c}0.269 * * * \\
(0.051)\end{array}$ & $\begin{array}{c}0.136 * * * \\
(0.025)\end{array}$ & $\begin{array}{c}0.255^{* * * *} \\
(0.052)\end{array}$ & $\begin{array}{c}0.147 * * * \\
(0.025)\end{array}$ \\
\hline $\ln ($ Size $)$ & $\begin{array}{c}0.219 * * * \\
(0.016)\end{array}$ & $\begin{array}{c}0.499 * * * \\
(0.013)\end{array}$ & $\begin{array}{c}0.212 * * * \\
(0.016)\end{array}$ & $\begin{array}{c}0.509 * * * \\
(0.013)\end{array}$ & $\begin{array}{c}0.263 * * * \\
(0.023)\end{array}$ & $\begin{array}{c}0.666^{* * * *} \\
(0.013)\end{array}$ & $\begin{array}{c}0.251 * * * \\
(0.024)\end{array}$ & $\begin{array}{c}0.682 * * * \\
(0.013)\end{array}$ \\
\hline Subsidy dummy t-1 & $\begin{array}{c}0.185 * * * \\
(0.030)\end{array}$ & $\begin{array}{c}0.272 * * * \\
(0.023)\end{array}$ & $\begin{array}{c}0.183 * * * \\
(0.030)\end{array}$ & $\begin{array}{c}0.272 * * * \\
(0.023)\end{array}$ & $\begin{array}{c}0.205 * * * \\
(0.043)\end{array}$ & $\begin{array}{c}0.280 * * * \\
(0.023)\end{array}$ & $\begin{array}{c}0.205^{* * * *} \\
(0.043)\end{array}$ & $\begin{array}{c}0.278 * * * \\
(0.023)\end{array}$ \\
\hline Sales growth & $\begin{array}{c}0.117 * * * \\
(0.029)\end{array}$ & $\begin{array}{c}0.014 \\
(0.023)\end{array}$ & $\begin{array}{c}0.101 * * * \\
(0.030)\end{array}$ & $\begin{array}{c}0.037 \\
(0.024)\end{array}$ & $\begin{array}{c}0.111 * * * \\
(0.035)\end{array}$ & $\begin{array}{c}0.039 * * \\
(0.018)\end{array}$ & $\begin{array}{c}0.096 * * * \\
(0.037)\end{array}$ & $\begin{array}{c}0.051 * * * \\
(0.018)\end{array}$ \\
\hline Other obstacles & $\begin{array}{c}-0.065^{* *} \\
(0.026)\end{array}$ & $\begin{array}{l}-0.017 \\
(0.020)\end{array}$ & $\begin{array}{l}-0.027 \\
(0.026)\end{array}$ & $\begin{array}{c}0.007 \\
(0.020)\end{array}$ & $\begin{array}{c}-0.247 * * * \\
(0.037)\end{array}$ & $\begin{array}{l}-0.017 \\
(0.019)\end{array}$ & $\begin{array}{c}-0.216^{* * *} * \\
(0.038)\end{array}$ & $\begin{array}{c}0.008 \\
(0.019)\end{array}$ \\
\hline Constant & $\begin{array}{c}-2.710 * * * \\
(0.100)\end{array}$ & $\begin{array}{c}7.292 * * * \\
(0.095)\end{array}$ & $\begin{array}{c}-2.791 * * * \\
(0.114)\end{array}$ & $\begin{array}{c}7.501^{* * * *} \\
(0.100)\end{array}$ & $\begin{array}{c}-2.571 * * * \\
(0.147)\end{array}$ & $\begin{array}{c}6.998 * * * \\
(0.084)\end{array}$ & $\begin{array}{c}-2.691 * * * \\
(0.164)\end{array}$ & $\begin{array}{c}7.219 * * * \\
(0.090)\end{array}$ \\
\hline & 18,730 & 10,774 & 18,730 & 10,774 & 11,736 & 8,985 & 11,736 & 8,985 \\
\hline$\rho_{\mathrm{u} 1 \mathrm{u} 2}$ & $\begin{array}{r}0.3 \\
(0\end{array}$ & & $\begin{array}{r}0.2 \\
(0\end{array}$ & & $\begin{array}{r}0.29 \\
(0 .\end{array}$ & $\begin{array}{l}* * * \\
35)\end{array}$ & $\begin{array}{r}0.28 \\
(0 .\end{array}$ & $\begin{array}{l}* * * \\
35)\end{array}$ \\
\hline$\rho_{\varepsilon 1 \varepsilon 2}$ & $\begin{array}{r}0.6 \\
(0\end{array}$ & *** & $\begin{array}{r}0.6 \\
(0\end{array}$ & *** & $\begin{array}{r}0.63 \\
(0 .\end{array}$ & **** & $\begin{array}{r}0.62 \\
(0.1\end{array}$ & *** \\
\hline$\sigma_{\mathrm{u} 1}$ & $\begin{array}{r}-0.7 \\
(0 .\end{array}$ & $\begin{array}{l}* * * \\
5)\end{array}$ & $\begin{array}{r}-0.6 \\
(0\end{array}$ & $\begin{array}{l}* * * \\
55)\end{array}$ & $\begin{array}{r}-0.6 \\
(0.6\end{array}$ & $\begin{array}{l}* * * * \\
77)\end{array}$ & $\begin{array}{r}-0.60 \\
(0.6\end{array}$ & $\begin{array}{l}* * * \\
5)\end{array}$ \\
\hline$\sigma_{\mathrm{u} 2}$ & $\begin{array}{r}-0.3 \\
(0 . \\
-0.0 \\
(0 .\end{array}$ & $\begin{array}{l}* * * \\
8) \\
* * * \\
9)\end{array}$ & $\begin{array}{r}-0.3 \\
(0 \\
-0.0 \\
(0\end{array}$ & $\begin{array}{l}* * * \\
18) \\
* * * \\
9)\end{array}$ & $\begin{array}{r}-0.37 \\
(0 . \\
-0.18 \\
(0 .\end{array}$ & $\begin{array}{l}\text { *** } \\
18) \\
* * * \\
99)\end{array}$ & $\begin{array}{r}-0.38 \\
(0.1 \\
-0.1 \\
(0.8\end{array}$ & $\begin{array}{l}* * * \\
8) \\
* * * \\
9)\end{array}$ \\
\hline
\end{tabular}


Table 9. Dynamic type 2 tobit estimates (Knowledge Intensive Services and Less Knowledge Intensive Services)

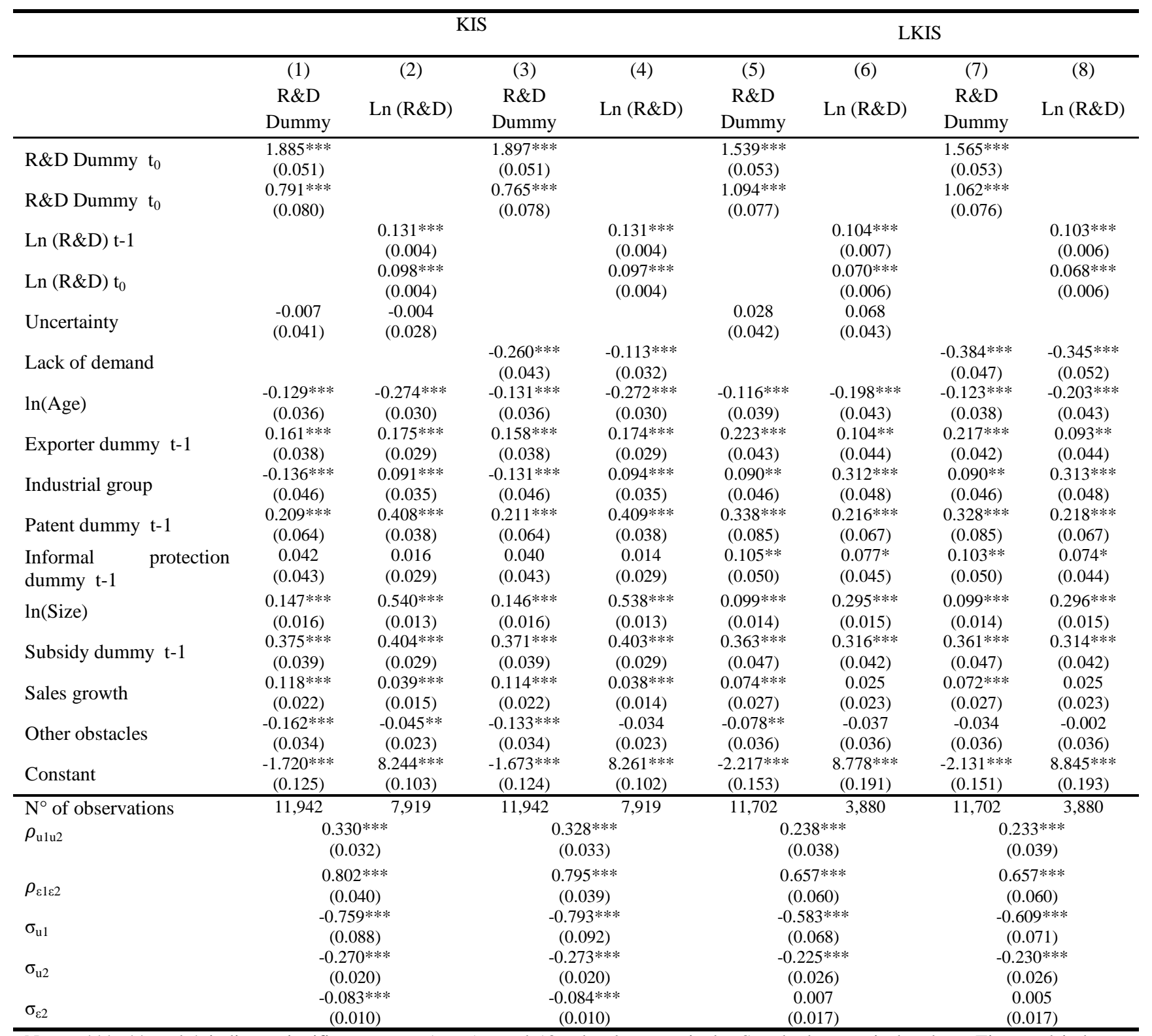

Notes; $* * *, * *$ and $*$ indicate significance on a $1 \%, 5 \%$ and $10 \%$ level, respectively. Standard errors in brackets. Time and industry dummies are included. 


\section{APPENDIX}

Table A1. The variables: acronyms and definitions.

Dependent variables (Innovative Inputs)

R\&D dummy Dummy $=1$ if firm's R\&D (both internal and external) expenditures are positive

$\ln (R \& D) \quad$ Natural $\log$ of the total firm's expenditures in R\&D (both internal and external)

\section{Independent variables (control variables)}

$\ln$ (Age) Natural log of the firm's age (calculated as years elapsed since founding)

Exporter dummy Dummy $=1$ if the firm have traded in an international market during the three year period; 0 otherwise

Industrial group Dummy $=1$ if the firm is part of an industrial group, 0 otherwise

Patent dummy Dummy $=1$ if the firm uses patents; 0 otherwise

Informal Dummy $=1$ if the firm adopts others instruments of protection than patents; protection dummy 0 otherwise

$\ln ($ Size $) \quad$ Log of the total number of firm's employees

Subsidy dummy Dummy $=1$ if the firm has received public support for innovation; 0 otherwise

Sales growth Growth rates of sales (calculated by taking logarithmic differences of sales levels)

Other obstacles Dummy $=1$ if the firm reports an higher degree of importance (from period $t$ to period $\mathrm{t}+1$ ) for at least one of the remaining obstacles variables; 0 otherwise

\section{Independent variables (Obstacle demand variables)}

Lack of demand Dummy=1 if the firm reports an higher degree of importance (from period $t$ to period $t+1$ ) for the obstacles variables "it was not necessary to innovate due to the Lack of demand for innovation"; 0 otherwise

Uncertainty Dummy=1 if the firm reports an higher degree of importance (from period $t$ to period $t+1$ ) for the obstacles variables "Uncertain demand for innovative goods or services"; 0 otherwise 
Table A2. Robustness check: Dynamic type 2 tobit estimates with both the demand obstacles variable

\begin{tabular}{|c|c|c|c|c|c|c|c|c|c|c|}
\hline & \multicolumn{2}{|c|}{ Whole Sample } & \multicolumn{2}{|c|}{ LMLt } & \multicolumn{2}{|c|}{$\mathrm{HMHt}$} & \multicolumn{2}{|c|}{ KIS } & \multicolumn{2}{|c|}{ LKIS } \\
\hline & (1) & (2) & (3) & (4) & (5) & (6) & (7) & (8) & (9) & (10) \\
\hline & $R \& D$ & & $R \& D$ & & $R \& D$ & & $R \& D$ & & $R \& D$ & \\
\hline & Dummy & $\operatorname{Ln}(\mathrm{R} \& \mathrm{D})$ & Dummy & $\operatorname{Ln}(\mathrm{R} \& \mathrm{D})$ & Dummy & $\operatorname{Ln}(\mathrm{R} \& \mathrm{D})$ & Dummy & $\operatorname{Ln}(\mathrm{R} \& \mathrm{D})$ & Dummy & $\operatorname{Ln}(\mathrm{R} \& \mathrm{D})$ \\
\hline \multirow[t]{2}{*}{ RD Dummy $\quad t-1$} & $1.745^{* * *}$ & & $1.743^{* * *}$ & & $1.942 * * *$ & & $1.886^{* * * *}$ & & $1.546^{* * *}$ & \\
\hline & $(0.023)$ & & $(0.036)$ & & $(0.053)$ & & $(0.051)$ & & $(0.053)$ & \\
\hline \multirow{2}{*}{ RD Dummy t 0} & $0.963 * * *$ & & $0.767 * * *$ & & $0.910 * * *$ & & $0.786 * * *$ & & $1.080 * * *$ & \\
\hline & $(0.036)$ & & $(0.054)$ & & $(0.094)$ & & $(0.079)$ & & $(0.077)$ & \\
\hline $\ln (\mathrm{RD}) \mathrm{t}-1$ & & $\begin{array}{c}0.115 * * * \\
(0.002)\end{array}$ & & $\begin{array}{c}0.109^{* * *} * \\
(0.004)\end{array}$ & & $\begin{array}{c}0.113 * * * \\
(0.004)\end{array}$ & & $\begin{array}{c}0.131 * * * \\
(0.004)\end{array}$ & & $\begin{array}{c}0.103 * * * \\
(0.006)\end{array}$ \\
\hline \multirow[t]{2}{*}{$\ln (\mathrm{RD}) \mathrm{t} 0$} & & $0.093 * * *$ & & $0.065^{* * *}$ & & $0.096 * * *$ & & $0.098 * * *$ & & $0.068 * * *$ \\
\hline & & $(0.002)$ & & $(0.004)$ & & $(0.004)$ & & $(0.004)$ & & $(0.006)$ \\
\hline \multirow{2}{*}{$\ln ($ Age $)$} & $-0.048 * * *$ & $-0.133 * * *$ & -0.019 & -0.009 & -0.027 & $-0.064 * * *$ & $-0.129 * * *$ & $-0.274 * * *$ & -0.120 *** & $-0.198 * * *$ \\
\hline & $(0.017)$ & $(0.014)$ & $(0.026)$ & $(0.024)$ & $(0.036)$ & $(0.022)$ & $(0.036)$ & $(0.030)$ & $(0.039)$ & $(0.043)$ \\
\hline \multirow[t]{2}{*}{ Exporter dummy t-1 } & $0.276 * * *$ & $0.192 * * *$ & $0.335 * * *$ & $0.208 * * *$ & $0.248 * * *$ & -0.009 & $0.160 * * *$ & $0.175^{* * *}$ & $0.222 * * *$ & $0.105 * *$ \\
\hline & $(0.021)$ & $(0.017)$ & $(0.036)$ & $(0.034)$ & $(0.055)$ & $(0.037)$ & $(0.038)$ & $(0.029)$ & $(0.043)$ & $(0.044)$ \\
\hline \multirow[t]{2}{*}{ Industrial group } & $0.044 * *$ & $0.259^{* * * *}$ & $0.092^{* *}$ & $0.245^{* * *}$ & -0.053 & $0.320 * * *$ & $-0.136 * * *$ & $0.091 * * *$ & $0.089^{*}$ & $0.318 * * *$ \\
\hline & $(0.022)$ & $(0.018)$ & $(0.036)$ & $(0.030)$ & $(0.052)$ & $(0.032)$ & $(0.046)$ & $(0.035)$ & $(0.046)$ & $(0.048)$ \\
\hline \multirow[t]{2}{*}{ Patent dummy t-1 } & $0.218 * * *$ & $0.250 * * *$ & $0.214 * * *$ & $0.157 * * *$ & 0.095 & $0.139 * * *$ & $0.209 * * *$ & $0.408 * * *$ & $0.335^{* * *}$ & $0.217 * * *$ \\
\hline & $(0.030)$ & $(0.018)$ & $(0.046)$ & $(0.031)$ & $(0.060)$ & $(0.028)$ & $(0.064)$ & $(0.038)$ & $(0.085)$ & $(0.067)$ \\
\hline \multirow[t]{2}{*}{ Informal protect. dummy t- 1} & $0.129 * * *$ & $0.053 * * *$ & $0.136 * * *$ & 0.004 & $0.268 * * *$ & $0.136 * * *$ & 0.040 & 0.015 & $0.103 * *$ & 0.073 \\
\hline & $(0.022)$ & $(0.015)$ & $(0.034)$ & $(0.025)$ & $(0.051)$ & $(0.025)$ & $(0.043)$ & $(0.029)$ & $(0.050)$ & $(0.045)$ \\
\hline \multirow[t]{2}{*}{$\ln ($ Size $)$} & $0.156^{* * *}$ & $0.494 * * *$ & $0.218 * * *$ & $0.500 * * *$ & $0.262 * * *$ & $0.667 * * *$ & $0.147 * * *$ & $0.540 * * *$ & $0.099 * * *$ & $0.295 * * *$ \\
\hline & $(0.008)$ & $(0.006)$ & $(0.016)$ & $(0.013)$ & $(0.023)$ & $(0.013)$ & $(0.016)$ & $(0.013)$ & $(0.014)$ & $(0.015)$ \\
\hline \multirow[t]{2}{*}{ Subsidy dummy t-1 } & $0.272 * * *$ & $0.330 * * *$ & $0.187 * * *$ & $0.273 * * *$ & $0.205 * * *$ & $0.280 * * *$ & $0.374 * * *$ & $0.404 * * *$ & $0.361 * * *$ & $0.318^{* * *}$ \\
\hline & $(0.019)$ & $(0.014)$ & $(0.030)$ & $(0.023)$ & $(0.043)$ & $(0.023)$ & $(0.039)$ & $(0.029)$ & $(0.047)$ & $(0.042)$ \\
\hline \multirow{2}{*}{ Sales growth } & $0.102 * * *$ & $0.038 * * *$ & $0.118 * * *$ & 0.014 & $0.110 * * *$ & $0.038 * *$ & $0.117 * * *$ & $0.038 * * *$ & $0.076 * * *$ & 0.027 \\
\hline & $(0.014)$ & $(0.010)$ & $(0.029)$ & $(0.023)$ & $(0.035)$ & $(0.018)$ & $(0.022)$ & $(0.015)$ & $(0.027)$ & $(0.023)$ \\
\hline \multirow{2}{*}{ Dem. obst.(both incr.) } & $-0.210 * * *$ & $-0.139 * * *$ & $-0.216 * * *$ & $-0.157 * * *$ & $-0.166^{* *}$ & $-0.122 * * *$ & $-0.149 * *$ & -0.038 & $-0.293 * * *$ & $-0.286 * * *$ \\
\hline & $(0.031)$ & $(0.025)$ & $(0.049)$ & $(0.042)$ & $(0.072)$ & $(0.044)$ & $(0.065)$ & $(0.050)$ & $(0.070)$ & $(0.079)$ \\
\hline \multirow{2}{*}{ Other obstacles (incr.) } & $-0.118 * * *$ & $-0.023 * *$ & $-0.064 * *$ & -0.011 & $-0.248 * * *$ & -0.016 & $-0.161 * * *$ & $-0.044 * *$ & $-0.077 * *$ & -0.029 \\
\hline & $(0.016)$ & $(0.011)$ & $(0.026)$ & $(0.020)$ & $(0.037)$ & $(0.019)$ & $(0.034)$ & $(0.022)$ & $(0.036)$ & $(0.036)$ \\
\hline \multirow[t]{2}{*}{ Constant } & $-2.498 * * *$ & $7.394 * * *$ & $-2.686 * * *$ & $7.328 * * *$ & $-2.547 * * *$ & $7.015 * * *$ & $-1.709 * * *$ & $8.244 * * *$ & $-2.172 * * *$ & $8.808 * * *$ \\
\hline & $(0.069)$ & $(0.056)$ & (0.099) & $(0.095)$ & $(0.146)$ & $(0.084)$ & $(0.125)$ & $(0.102)$ & $(0.152)$ & (0.192) \\
\hline Observations & 54,110 & 31,558 & 18,730 & 10,774 & 11,736 & 8,985 & 111,942 & 7,919 & $\begin{array}{l}11,702 \\
\end{array}$ & 3,880 \\
\hline
\end{tabular}


Table A2 (continued). Robustness check: Dynamic type 2 tobit estimates with both the demand obstacles variable

\begin{tabular}{|c|c|c|c|c|c|}
\hline$\rho_{\mathrm{u} 1 \mathrm{u} 2}$ & $\begin{array}{c}0.308 * * * \\
(0.015)\end{array}$ & $\begin{array}{c}0.309 * * * \\
(0.027)\end{array}$ & $\begin{array}{c}0.294 * * * \\
(0.035)\end{array}$ & $\begin{array}{c}0.330 * * * \\
(0.032)\end{array}$ & $\begin{array}{c}0.234 * * * \\
(0.039)\end{array}$ \\
\hline$\rho_{\varepsilon 1 \varepsilon 2}$ & $\begin{array}{c}0.713 * * * \\
(0.020)\end{array}$ & $\begin{array}{c}0.675 * * * \\
(0.035)\end{array}$ & $\begin{array}{c}0.636 * * * \\
(0.035)\end{array}$ & $\begin{array}{c}0.802 * * * \\
(0.040)\end{array}$ & $\begin{array}{c}0.657 * * * \\
(0.060)\end{array}$ \\
\hline$\sigma_{\mathrm{u} 1}$ & $\begin{array}{c}-0.616^{* * * *} \\
(0.032)\end{array}$ & $\begin{array}{c}-0.731 * * * \\
(0.055)\end{array}$ & $\begin{array}{c}-0.649 * * * \\
(0.078)\end{array}$ & $\begin{array}{c}-0.767 * * * \\
(0.089)\end{array}$ & $\begin{array}{c}-0.590 * * * \\
(0.069)\end{array}$ \\
\hline$\sigma_{\mathrm{u} 2}$ & $\begin{array}{c}-0.301 * * * \\
(0.010)\end{array}$ & $\begin{array}{c}-0.340 * * * \\
(0.018)\end{array}$ & $\begin{array}{c}-0.380 * * * \\
(0.018)\end{array}$ & $\begin{array}{c}-0.271 * * * \\
(0.020)\end{array}$ & $\begin{array}{c}-0.228 * * * \\
(0.026)\end{array}$ \\
\hline$\sigma_{\varepsilon 2}$ & $\begin{array}{c}-0.078 \text { **** } \\
(0.005)\end{array}$ & $\begin{array}{c}-0.070 \text { *** } \\
(0.009)\end{array}$ & $\begin{array}{c}-0.190 * * * \\
(0.009)\end{array}$ & $\begin{array}{c}-0.083 \text { *** } \\
(0.010)\end{array}$ & $\begin{array}{c}0.007 \\
(0.017)\end{array}$ \\
\hline
\end{tabular}


Table A3. Robustness check: Dynamic type 2 tobit with the obstacles variables identifying those firms assessing as highly important the lack/uncertainty of demand (whole sample).

\begin{tabular}{|c|c|c|c|c|}
\hline & $\begin{array}{c}\text { (1) } \\
\text { R\&D Dummy }\end{array}$ & $\begin{array}{c}(2) \\
\operatorname{Ln}(\mathrm{R} \& \mathrm{D}) \\
\end{array}$ & $\begin{array}{c}\text { (3) } \\
\text { R\&D Dummy }\end{array}$ & $\begin{array}{c}(4) \\
\operatorname{Ln}(\mathrm{R} \& \mathrm{D}) \\
\end{array}$ \\
\hline R\&D Dummy $t-1$ & $\begin{array}{c}1.741 * * * \\
(0.023)\end{array}$ & & $\begin{array}{c}1.744 * * * \\
(0.023)\end{array}$ & \\
\hline R\&D Dummy $t_{0}$ & $\begin{array}{c}0.972^{* * * *} \\
(0.036)\end{array}$ & & $\begin{array}{c}0.936^{* * * *} \\
(0.036)\end{array}$ & \\
\hline $\operatorname{Ln}(\mathrm{R} \& \mathrm{D}) \mathrm{t}-1$ & & $\begin{array}{c}0.115 * * * \\
(0.002)\end{array}$ & & $\begin{array}{c}0.114 * * * \\
(0.002)\end{array}$ \\
\hline $\operatorname{Ln}(\mathrm{R} \& D) \mathrm{t}_{0}$ & & $\begin{array}{c}0.093 * * * \\
(0.002)\end{array}$ & & $\begin{array}{c}0.092 * * * \\
(0.002)\end{array}$ \\
\hline Uncertainty (high) & $\begin{array}{l}-0.009 \\
(0.020)\end{array}$ & $\begin{array}{c}-0.054 * * * \\
(0.015)\end{array}$ & & \\
\hline Lack of demand (high) & & & $\begin{array}{c}-0.742 * * * \\
(0.038)\end{array}$ & $\begin{array}{c}-0.393 * * * \\
(0.040)\end{array}$ \\
\hline $\ln ($ Age $)$ & $\begin{array}{c}-0.048 * * * \\
(0.017)\end{array}$ & $\begin{array}{c}-0.133 * * * \\
(0.014)\end{array}$ & $\begin{array}{c}-0.045^{* * *} \\
(0.017)\end{array}$ & $\begin{array}{c}-0.133 * * * \\
(0.014)\end{array}$ \\
\hline Exporter dummy $\mathrm{t}-1$ & $\begin{array}{c}0.279 * * * \\
(0.021)\end{array}$ & $\begin{array}{c}0.193 * * * \\
(0.017)\end{array}$ & $\begin{array}{c}0.264 * * * \\
(0.021)\end{array}$ & $\begin{array}{c}0.188 * * * \\
(0.017)\end{array}$ \\
\hline Industrial group & $\begin{array}{c}0.044 * * \\
(0.022)\end{array}$ & $\begin{array}{c}0.258 * * * \\
(0.018)\end{array}$ & $\begin{array}{l}0.041 * \\
(0.022)\end{array}$ & $\begin{array}{c}0.260 * * * \\
(0.018)\end{array}$ \\
\hline Patent dummy t-1 & $\begin{array}{c}0.218 * * * \\
(0.030)\end{array}$ & $\begin{array}{c}0.251 * * * \\
(0.018)\end{array}$ & $\begin{array}{c}0.214 * * * \\
(0.030)\end{array}$ & $\begin{array}{c}0.252^{* * * *} \\
(0.018)\end{array}$ \\
\hline Informal protection dummy $\mathrm{t}-1$ & $\begin{array}{c}0.131 * * * \\
(0.022)\end{array}$ & $\begin{array}{c}0.054 * * * \\
(0.015)\end{array}$ & $\begin{array}{c}0.122 * * * \\
(0.022)\end{array}$ & $\begin{array}{c}0.050 * * * \\
(0.015)\end{array}$ \\
\hline $\ln ($ Size $)$ & $\begin{array}{c}0.156^{* * * *} \\
(0.008)\end{array}$ & $\begin{array}{c}0.494 * * * \\
(0.006)\end{array}$ & $\begin{array}{c}0.154 * * * \\
(0.008)\end{array}$ & $\begin{array}{c}0.494 * * * \\
(0.006)\end{array}$ \\
\hline Subsidy dummy t-1 & $\begin{array}{c}0.273 * * * \\
(0.019)\end{array}$ & $\begin{array}{c}0.331 * * * \\
(0.014)\end{array}$ & $\begin{array}{c}0.260 * * * \\
(0.019)\end{array}$ & $\begin{array}{c}0.329 * * * \\
(0.014)\end{array}$ \\
\hline Sales growth & $\begin{array}{c}0.103 * * * \\
(0.014)\end{array}$ & $\begin{array}{c}0.038 * * * \\
(0.010)\end{array}$ & $\begin{array}{c}0.096 * * * \\
(0.014)\end{array}$ & $\begin{array}{c}0.037 * * * \\
(0.010)\end{array}$ \\
\hline Other obstacles & $\begin{array}{c}-0.118 * * * \\
(0.016)\end{array}$ & $\begin{array}{c}-0.025 * * \\
(0.011)\end{array}$ & $\begin{array}{c}-0.118 * * * \\
(0.016)\end{array}$ & $\begin{array}{c}-0.025 * * \\
(0.011)\end{array}$ \\
\hline Constant & $\begin{array}{c}-2.519 * * * \\
(0.070)\end{array}$ & $\begin{array}{c}7.401 * * * \\
(0.056)\end{array}$ & $\begin{array}{c}-2.431 * * * \\
(0.069)\end{array}$ & $\begin{array}{c}7.412^{* * *} \\
(0.056)\end{array}$ \\
\hline $\mathrm{N}^{\circ}$ of observations & 54,110 & 31,558 & 54,110 & 31,558 \\
\hline$\rho_{\mathrm{u} 1 \mathrm{u} 2}$ & \multicolumn{2}{|c|}{$\begin{array}{c}0.310^{* * *} \\
(0.015)\end{array}$} & \multicolumn{2}{|c|}{$\begin{array}{c}0.307 * * * \\
(0.015)\end{array}$} \\
\hline$\rho_{\varepsilon 1 \varepsilon 2}$ & \multicolumn{2}{|c|}{$0.714 * * *$} & \multicolumn{2}{|c|}{$\begin{array}{c}0.709 * * * \\
(0.020)\end{array}$} \\
\hline$\sigma_{\mathrm{u} 1}$ & \multicolumn{2}{|c|}{$-0.607 * * *$} & $-0.630 * * *$ & \\
\hline$\sigma_{\mathrm{u} 2}$ & \multicolumn{2}{|c|}{$-0.299 * * *$} & \multicolumn{2}{|c|}{$-0.301 * * *$} \\
\hline$\sigma_{\varepsilon 2}$ & \multicolumn{2}{|c|}{$-0.078 * * *$} & \multicolumn{2}{|c|}{$\begin{array}{c}-0.079 * * * \\
(0.005)\end{array}$} \\
\hline
\end{tabular}

Notes; $* * *, * *$ and $*$ indicate significance on a $1 \%, 5 \%$ and $10 \%$ level, respectively. Standard errors in brackets. Time and industry dummies are included. 
Table A4. Robustness check: Dynamic type 2 tobit with the obstacles variables identifying those firms assessing as highly important the lack/uncertainty of demand (manufacturing sectors)

\begin{tabular}{|c|c|c|c|c|c|c|c|c|}
\hline & \multicolumn{4}{|c|}{ Low/medium-low tech Sectors } & \multicolumn{4}{|c|}{ High/medium-high tech Sectors } \\
\hline & $\begin{array}{c}(1) \\
\text { R\&D } \\
\text { Dummy }\end{array}$ & $\begin{array}{c}(2) \\
\operatorname{Ln}(\mathrm{R} \& D)\end{array}$ & $\begin{array}{c}(3) \\
\text { R\&D } \\
\text { Dummy }\end{array}$ & $\begin{array}{c}(4) \\
\text { Ln } \\
(\mathrm{R} \& D)\end{array}$ & $\begin{array}{c}(5) \\
\text { R\&D } \\
\text { Dummy }\end{array}$ & $\begin{array}{c}(6) \\
\text { Ln } \\
(\mathrm{R} \& D)\end{array}$ & $\begin{array}{c}(7) \\
\text { R\&D } \\
\text { Dummy }\end{array}$ & $\begin{array}{c}(8) \\
\text { Ln } \\
(\mathrm{R} \& D)\end{array}$ \\
\hline R\&D Dummy t-1 & $\begin{array}{c}1.706^{* * * *} \\
(0.038)\end{array}$ & & $\begin{array}{c}1.740 * * * \\
(0.036)\end{array}$ & & $\begin{array}{c}1.890^{* * * *} \\
(0.054)\end{array}$ & & $\begin{array}{c}1.939 * * * \\
(0.053)\end{array}$ & \\
\hline $\mathrm{R} \& \mathrm{D}$ Dummy $\mathrm{t}_{0}$ & $\begin{array}{c}0.788 * * * \\
(0.056)\end{array}$ & & $\begin{array}{c}0.775 * * * \\
(0.054)\end{array}$ & & $0.961 * * *$ & & $\begin{array}{c}0.919 * * * \\
(0.094)\end{array}$ & \\
\hline $\operatorname{Ln}(\mathrm{R} \& \mathrm{D}) \mathrm{t}-1$ & & $\begin{array}{c}0.106 * * * \\
(0.004)\end{array}$ & & $\begin{array}{c}0.109 * * * \\
(0.004)\end{array}$ & & $\begin{array}{c}0.110 * * * \\
(0.004)\end{array}$ & & $\begin{array}{c}0.113 * * * \\
(0.004)\end{array}$ \\
\hline $\operatorname{Ln}(\mathrm{R} \& \mathrm{D}) \mathrm{t}_{0}$ & & $\begin{array}{c}0.066 * * * \\
(0.004)\end{array}$ & & $\begin{array}{c}0.065 * * * \\
(0.004)\end{array}$ & & $\begin{array}{c}0.097 * * * \\
(0.004)\end{array}$ & & $\begin{array}{c}0.096 * * * \\
(0.004)\end{array}$ \\
\hline Uncertainty (high) & & & $\begin{array}{c}0.005 \\
(0.032)\end{array}$ & $\begin{array}{c}0.015 \\
(0.026)\end{array}$ & & & $\begin{array}{l}-0.014 \\
(0.045)\end{array}$ & $\begin{array}{l}-0.025 \\
(0.025)\end{array}$ \\
\hline Lack of demand (high) & $\begin{array}{c}-0.781 * * * \\
(0.061)\end{array}$ & $\begin{array}{c}-0.413 * * * \\
(0.080)\end{array}$ & & & $\begin{array}{c}-0.673^{* * * *} \\
(0.092)\end{array}$ & $\begin{array}{c}-0.207 * * * \\
(0.073)\end{array}$ & & \\
\hline $\ln ($ Age $)$ & $\begin{array}{c}0.012 \\
(0.027)\end{array}$ & $\begin{array}{l}-0.041^{*} \\
(0.024)\end{array}$ & $\begin{array}{l}-0.019 \\
(0.026)\end{array}$ & $\begin{array}{l}-0.009 \\
(0.024)\end{array}$ & $\begin{array}{l}-0.001 \\
(0.038)\end{array}$ & $\begin{array}{c}-0.109 * * * \\
(0.023)\end{array}$ & $\begin{array}{l}-0.027 \\
(0.037)\end{array}$ & $\begin{array}{c}-0.063 * * * * \\
(0.022)\end{array}$ \\
\hline Exporter dummy t-1 & $\begin{array}{c}0.335 * * * \\
(0.037)\end{array}$ & $\begin{array}{c}0.188 \text { *** } \\
(0.034)\end{array}$ & $\begin{array}{c}0.339 * * * \\
(0.036)\end{array}$ & $\begin{array}{c}0.210 \text { *** } \\
(0.034)\end{array}$ & $\begin{array}{c}0.260 * * * \\
(0.056)\end{array}$ & $\begin{array}{l}-0.013 \\
(0.037)\end{array}$ & $\begin{array}{c}0.252 * * * \\
(0.055)\end{array}$ & $\begin{array}{c}-0.007 \\
(0.037)\end{array}$ \\
\hline Industrial group & $\begin{array}{c}0.115 * * * \\
(0.037)\end{array}$ & $\begin{array}{c}0.226 * * * \\
(0.030)\end{array}$ & $\begin{array}{c}0.092 * * \\
(0.036)\end{array}$ & $\begin{array}{c}0.246 * * * \\
(0.030)\end{array}$ & $\begin{array}{l}-0.042 \\
(0.053)\end{array}$ & $\begin{array}{c}0.283 * * * \\
(0.032)\end{array}$ & $\begin{array}{l}-0.052 \\
(0.052)\end{array}$ & $\begin{array}{c}0.321 * * * \\
(0.032)\end{array}$ \\
\hline Patent dummy t-1 & $\begin{array}{c}0.214 * * * \\
(0.047)\end{array}$ & $\begin{array}{c}0.170 * * * \\
(0.031)\end{array}$ & $\begin{array}{c}0.216 * * * \\
(0.046)\end{array}$ & $\begin{array}{c}0.156 * * * \\
(0.031)\end{array}$ & $\begin{array}{c}0.096 \\
(0.061)\end{array}$ & $\begin{array}{c}0.153 * * * \\
(0.028)\end{array}$ & $\begin{array}{c}0.094 \\
(0.060)\end{array}$ & $\begin{array}{c}0.140 * * * * \\
(0.028)\end{array}$ \\
\hline $\begin{array}{l}\text { Informal protection } \\
\text { dummy t-1 }\end{array}$ & $\begin{array}{c}0.127 * * * \\
(0.035)\end{array}$ & $\begin{array}{c}0.015 \\
(0.025)\end{array}$ & $\begin{array}{c}0.139 * * * \\
(0.034)\end{array}$ & $\begin{array}{c}0.006 \\
(0.025)\end{array}$ & $\begin{array}{c}0.247 * * * \\
(0.052)\end{array}$ & $\begin{array}{c}0.144 * * * \\
(0.025)\end{array}$ & $\begin{array}{c}0.268 * * * \\
(0.051)\end{array}$ & $\begin{array}{c}0.136 * * * \\
(0.025)\end{array}$ \\
\hline $\ln ($ Size $)$ & $\begin{array}{c}0.208 * * * \\
(0.016)\end{array}$ & $\begin{array}{c}0.509 * * * \\
(0.013)\end{array}$ & $\begin{array}{l}0.219 * * * \\
(0.016)\end{array}$ & $\begin{array}{c}0.500 * * * \\
(0.013)\end{array}$ & $\begin{array}{l}0.254 * * * \\
(0.024)\end{array}$ & $\begin{array}{c}0.683 * * * \\
(0.013)\end{array}$ & $\begin{array}{c}0.263 * * * \\
(0.024)\end{array}$ & $\begin{array}{c}0.665^{* * * *} \\
(0.013)\end{array}$ \\
\hline Subsidy dummy $\mathrm{t}-1$ & $\begin{array}{c}0.165 * * * \\
(0.030)\end{array}$ & $\begin{array}{l}0.270 * * * \\
(0.023)\end{array}$ & $\begin{array}{c}0.185 * * * \\
(0.030)\end{array}$ & $\begin{array}{l}0.272 * * * \\
(0.023)\end{array}$ & $\begin{array}{c}0.194 * * * \\
(0.043)\end{array}$ & $\begin{array}{l}0.276^{* * * *} \\
(0.023)\end{array}$ & $\begin{array}{l}0.206 * * * \\
(0.043)\end{array}$ & $\begin{array}{c}0.281 * * * \\
(0.023)\end{array}$ \\
\hline Sales growth & $\begin{array}{c}0.095 * * * \\
(0.031)\end{array}$ & $\begin{array}{c}0.036 \\
(0.024)\end{array}$ & $\begin{array}{c}0.116^{* * * *} \\
(0.029)\end{array}$ & $\begin{array}{c}0.014 \\
(0.023)\end{array}$ & $\begin{array}{c}0.100 * * * \\
(0.037)\end{array}$ & $\begin{array}{c}0.054 * * * \\
(0.018)\end{array}$ & $\begin{array}{c}0.111 * * * \\
(0.035)\end{array}$ & $\begin{array}{c}0.039 * * \\
(0.018)\end{array}$ \\
\hline Other obstacles & $\begin{array}{c}-0.063 * * \\
(0.026)\end{array}$ & $\begin{array}{l}-0.004 \\
(0.020)\end{array}$ & $\begin{array}{c}-0.065^{* *} \\
(0.026)\end{array}$ & $\begin{array}{l}-0.012 \\
(0.020)\end{array}$ & $\begin{array}{c}-0.250 * * * \\
(0.038)\end{array}$ & $\begin{array}{l}-0.006 \\
(0.019)\end{array}$ & $\begin{array}{c}-0.247 * * * \\
(0.037)\end{array}$ & $\begin{array}{l}-0.017 \\
(0.019)\end{array}$ \\
\hline Constant & $\begin{array}{c}-2.780 * * * \\
(0.114)\end{array}$ & $\begin{array}{c}7.493 * * * \\
(0.101)\end{array}$ & $\begin{array}{c}-2.713 * * * \\
(0.100)\end{array}$ & $\begin{array}{c}7.310^{* * * *} \\
(0.095)\end{array}$ & $\begin{array}{c}-2.690 * * * \\
(0.163)\end{array}$ & $\begin{array}{c}7.208 * * * \\
(0.091)\end{array}$ & $\begin{array}{c}-2.566 * * * \\
(0.147)\end{array}$ & $\begin{array}{c}7.006 * * * \\
(0.084)\end{array}$ \\
\hline $\mathrm{N}^{\circ}$ of observations & 18,730 & 10,774 & 18,730 & 10,774 & 11,736 & 8,985 & 11,736 & 8,985 \\
\hline$\rho_{\mathrm{ulu} 2}$ & \multicolumn{2}{|c|}{$\begin{array}{c}0.298^{* * *} \\
(0.027)\end{array}$} & \multicolumn{2}{|c|}{$\begin{array}{c}0.311^{* * *} \\
(0.027)\end{array}$} & \multicolumn{2}{|c|}{$\begin{array}{l}0.284 * * * \\
(0.035)\end{array}$} & \multicolumn{2}{|c|}{$\begin{array}{c}0.295 * * * \\
(0.035)\end{array}$} \\
\hline$\rho_{\varepsilon 1 \varepsilon 2}$ & \multicolumn{2}{|c|}{$0.658^{* * *}$} & \multicolumn{2}{|c|}{$0.674 * * *$} & \multicolumn{2}{|c|}{$\begin{array}{c}0.631^{* * * *} \\
(0.036)\end{array}$} & \multicolumn{2}{|c|}{$\begin{array}{c}0.638 * * * \\
(0.035)\end{array}$} \\
\hline$\sigma_{\mathrm{u} 1}$ & \multicolumn{2}{|c|}{$-0.683^{* * *}$} & \multicolumn{2}{|c|}{$-0.720 * * *$} & & \multicolumn{2}{|c|}{$(0.077)$} \\
\hline$\sigma_{\mathrm{u} 2}$ & \multicolumn{2}{|c|}{$\begin{array}{c}-0.346^{* * *} * \\
(0.018)\end{array}$} & \multicolumn{2}{|c|}{$\begin{array}{c}-0.338 * * * \\
(0.018)\end{array}$} & \multicolumn{2}{|c|}{$-0.384 * * *$} & \multicolumn{2}{|c|}{$-0.379 * * *$} \\
\hline$\sigma_{\varepsilon 2}$ & \multicolumn{2}{|c|}{$-0.078 * * *$} & \multicolumn{2}{|c|}{$-0.069 * * *$} & \multicolumn{2}{|c|}{$-0.196 * * *$} & \multicolumn{2}{|c|}{$\begin{array}{c}-0.190 * * * * \\
(0.009)\end{array}$} \\
\hline
\end{tabular}


Table A5. Robustness check: Dynamic type 2 tobit estimations with the obstacles variables identifying those firms assessing as highly important the lack/uncertainty of demand (services sectors).

\begin{tabular}{|c|c|c|c|c|c|c|c|c|}
\hline & \multicolumn{4}{|c|}{ KIS } & \multicolumn{4}{|c|}{ LKIS } \\
\hline & (1) & (2) & (3) & (4) & (5) & (6) & (7) & (8) \\
\hline & R\&D & $\operatorname{Ln}(\mathrm{R} \& \mathrm{D})$ & R\&D & $\operatorname{Ln}(\mathrm{R} \& \mathrm{D})$ & R\&D & $\operatorname{Ln}(\mathrm{R} \& \mathrm{D})$ & R\&D & Ln \\
\hline & Dummy & & Dummy & & Dummy & & Dummy & $(\mathrm{R} \& \mathrm{D})$ \\
\hline \multirow{2}{*}{ R\&D Dummy t-1 } & $1.884 * * *$ & & $1.894 * * *$ & & $1.527 * * *$ & & $1.522 * * *$ & \\
\hline & $(0.051)$ & & $(0.049)$ & & $(0.053)$ & & $(0.050)$ & \\
\hline \multirow{2}{*}{$\mathrm{R} \& \mathrm{D}$ Dummy $\mathrm{t}_{0}$} & $0.792 * * *$ & & $0.753 * * *$ & & $1.057 * * *$ & & $1.103 * * *$ & \\
\hline & $(0.080)$ & & $(0.076)$ & & $(0.076)$ & & $(0.075)$ & \\
\hline Ln (R\&D) t-1 & & $\begin{array}{l}0.130 * * * \\
(0.004)\end{array}$ & & $\begin{array}{l}0.131 * * * \\
(0.004)\end{array}$ & & $\begin{array}{l}0.101 * * * \\
(0.006)\end{array}$ & & $\begin{array}{c}0.103 * * * \\
(0.006)\end{array}$ \\
\hline \multirow{2}{*}{$\operatorname{Ln}(R \& D) t_{0}$} & & $0.098 * * *$ & & $0.097 * * *$ & & $0.068 * * *$ & & $0.071 * * *$ \\
\hline & & $(0.004)$ & & $(0.004)$ & & $(0.006)$ & & $(0.006)$ \\
\hline \multirow{2}{*}{ Uncertainty (high) } & -0.039 & $-0.112 * * *$ & & & & & -0.016 & -0.001 \\
\hline & $(0.041)$ & $(0.028)$ & & & & & $(0.049)$ & $(0.051)$ \\
\hline Lack of demand (high) & & & $\begin{array}{c}-0.614 * * * \\
(0.079)\end{array}$ & $\begin{array}{c}-0.342 * * * \\
(0.079)\end{array}$ & $\begin{array}{c}-0.866^{* * * *} \\
(0.082)\end{array}$ & $\begin{array}{c}-0.603 * * * \\
(0.113)\end{array}$ & & \\
\hline $\ln ($ Age $)$ & $\begin{array}{c}-0.129 * * * \\
(0.036)\end{array}$ & $\begin{array}{c}-0.270 * * * \\
(0.030)\end{array}$ & $\begin{array}{c}-0.128 * * * \\
(0.035)\end{array}$ & $\begin{array}{c}-0.185^{* * * *} \\
(0.028)\end{array}$ & $\begin{array}{c}-0.125 * * * \\
(0.039)\end{array}$ & $\begin{array}{c}-0.208 * * * \\
(0.041)\end{array}$ & $\begin{array}{c}-0.116 * * * \\
(0.038)\end{array}$ & $\begin{array}{c}-0.142 * * * \\
(0.042)\end{array}$ \\
\hline Exporter dummy t-1 & $\begin{array}{l}0.161 * * * \\
(0.038)\end{array}$ & $\begin{array}{l}0.168 * * * \\
(0.029)\end{array}$ & $\begin{array}{c}0.154 * * * \\
(0.038)\end{array}$ & $\begin{array}{c}0.203 * * * \\
(0.029)\end{array}$ & $\begin{array}{l}0.203 * * * \\
(0.043)\end{array}$ & $\begin{array}{c}0.098 * * \\
(0.044)\end{array}$ & $\begin{array}{l}0.226 * * * \\
(0.043)\end{array}$ & $\begin{array}{c}0.122 * * * \\
(0.045)\end{array}$ \\
\hline Industrial group & $\begin{array}{c}-0.138 * * * \\
(0.046)\end{array}$ & $\begin{array}{c}0.088 * * \\
(0.034)\end{array}$ & $\begin{array}{c}-0.133 * * * \\
(0.046)\end{array}$ & $\begin{array}{c}0.132 * * * \\
(0.035)\end{array}$ & $\begin{array}{c}0.074 \\
(0.046)\end{array}$ & $\begin{array}{c}0.302 * * * \\
(0.048)\end{array}$ & $\begin{array}{l}0.089 * \\
(0.046)\end{array}$ & $\begin{array}{c}0.330 * * * \\
(0.049)\end{array}$ \\
\hline Patent dummy t-1 & $\begin{array}{l}0.210^{* * * *} \\
(0.064)\end{array}$ & $\begin{array}{c}0.413 * * * \\
(0.038)\end{array}$ & $\begin{array}{l}0.208 * * * \\
(0.064)\end{array}$ & $\begin{array}{c}0.415^{* * *} \\
(0.038)\end{array}$ & $\begin{array}{l}0.341 * * * \\
(0.086)\end{array}$ & $\begin{array}{c}0.220 * * * \\
(0.066)\end{array}$ & $\begin{array}{c}0.324 * * * \\
(0.085)\end{array}$ & $\begin{array}{c}0.182 * * * \\
(0.065)\end{array}$ \\
\hline $\begin{array}{l}\text { Informal protection } \\
\text { dummy t-1 }\end{array}$ & $\begin{array}{c}0.043 \\
(0.043)\end{array}$ & $\begin{array}{c}0.022 \\
(0.029)\end{array}$ & $\begin{array}{c}0.039 \\
(0.043)\end{array}$ & $\begin{array}{l}-0.001 \\
(0.029)\end{array}$ & $\begin{array}{l}0.094 * \\
(0.050)\end{array}$ & $\begin{array}{l}0.075^{*} \\
(0.044)\end{array}$ & $\begin{array}{l}0.104 * * \\
(0.050)\end{array}$ & $\begin{array}{c}0.070 \\
(0.045)\end{array}$ \\
\hline $\ln ($ Size $)$ & $\begin{array}{c}0.146^{* * * *} \\
(0.016)\end{array}$ & $\begin{array}{c}0.537 * * * \\
(0.013)\end{array}$ & $\begin{array}{c}0.145^{* * *} \\
(0.016)\end{array}$ & $\begin{array}{c}0.518 * * * \\
(0.012)\end{array}$ & $\begin{array}{c}0.100 * * * \\
(0.014)\end{array}$ & $\begin{array}{c}0.300 * * * \\
(0.015)\end{array}$ & $\begin{array}{c}0.098 * * * \\
(0.014)\end{array}$ & $\begin{array}{c}0.298 * * * \\
(0.015)\end{array}$ \\
\hline Subsidy dummy t-1 & $\begin{array}{c}0.377 * * * \\
(0.039)\end{array}$ & $\begin{array}{c}0.410 * * * \\
(0.029)\end{array}$ & $\begin{array}{c}0.371 * * * \\
(0.039)\end{array}$ & $\begin{array}{c}0.410 * * * \\
(0.029)\end{array}$ & $\begin{array}{c}0.348^{* * * *} \\
(0.047)\end{array}$ & $\begin{array}{c}0.304 * * * \\
(0.042)\end{array}$ & $\begin{array}{c}0.357 * * * \\
(0.047)\end{array}$ & $\begin{array}{c}0.299 * * * \\
(0.042)\end{array}$ \\
\hline Sales growth & $\begin{array}{c}0.118 * * * \\
(0.022)\end{array}$ & $\begin{array}{c}0.039 * * * \\
(0.014)\end{array}$ & $\begin{array}{c}0.117 * * * \\
(0.022)\end{array}$ & $\begin{array}{l}0.028^{*} \\
(0.015)\end{array}$ & $\begin{array}{c}0.065 * * \\
(0.027)\end{array}$ & $\begin{array}{c}0.023 \\
(0.023)\end{array}$ & $\begin{array}{c}0.080 * * * \\
(0.027)\end{array}$ & $\begin{array}{c}0.021 \\
(0.023)\end{array}$ \\
\hline Other obstacles & $\begin{array}{c}-0.164 * * * \\
(0.034)\end{array}$ & $\begin{array}{c}-0.044 * * \\
(0.022)\end{array}$ & $\begin{array}{c}-0.162 * * * \\
(0.034)\end{array}$ & $\begin{array}{c}-0.057 * * \\
(0.022)\end{array}$ & $\begin{array}{l}-0.069^{*} \\
(0.036)\end{array}$ & $\begin{array}{l}-0.028 \\
(0.036)\end{array}$ & $\begin{array}{c}-0.082 * * \\
(0.036)\end{array}$ & $\begin{array}{l}-0.054 \\
(0.036)\end{array}$ \\
\hline Constant & $\begin{array}{c}-1.709 * * * \\
(0.126)\end{array}$ & $\begin{array}{c}8.279 * * * \\
(0.101)\end{array}$ & $\begin{array}{c}-1.661 * * * \\
(0.109)\end{array}$ & $\begin{array}{c}8.019 * * * \\
(0.090)\end{array}$ & $\begin{array}{c}-2.085^{* * * *} \\
(0.151)\end{array}$ & $\begin{array}{c}8.855^{* * * *} \\
(0.185)\end{array}$ & $\begin{array}{c}-2.217 * * * \\
(0.136)\end{array}$ & $\begin{array}{c}8.560 * * * \\
(0.178)\end{array}$ \\
\hline $\mathrm{N}^{\circ}$ of observations & 11,942 & 7,919 & 11,942 & 7,919 & 11,702 & 3,880 & 11,702 & 3,880 \\
\hline$\rho_{\mathrm{u} 1 \mathrm{u} 2}$ & \multicolumn{2}{|c|}{$\begin{array}{c}0.330 * * * \\
(0.032)\end{array}$} & \multicolumn{2}{|c|}{$\begin{array}{c}0.337 * * * \\
(0.032)\end{array}$} & \multicolumn{2}{|c|}{$\begin{array}{c}0.243 * * * \\
(0.038)\end{array}$} & \multicolumn{2}{|c|}{$\begin{array}{c}0.261 * * * \\
(0.036)\end{array}$} \\
\hline$\rho_{\varepsilon 1 \varepsilon 2}$ & \multicolumn{2}{|c|}{$0.798 * * *$} & \multicolumn{2}{|c|}{$0.788 * * *$} & \multicolumn{2}{|c|}{$0.655^{* * *}$} & \multicolumn{2}{|c|}{$0.656 * * *$} \\
\hline$\sigma_{\mathrm{u} 1}$ & $\begin{array}{r}-0.7 \\
(0 .\end{array}$ & $\begin{array}{l}* * * \\
8)\end{array}$ & $\begin{array}{r}-0.7 \\
(0 .\end{array}$ & $\begin{array}{l}* * * \\
9)\end{array}$ & $\begin{array}{r}-0.58 \\
(0 .\end{array}$ & & $\begin{array}{r}-0.57 \\
(0.0\end{array}$ & \\
\hline & -0.2 & $* * *$ & -0.26 & $* * *$ & -0.2 & $* * *$ & -0.20 & \\
\hline$\sigma_{\mathrm{u} 2}$ & $(0$. & & $(0$. & & $(0$. & & $(0.0$ & \\
\hline & -0.08 & & $-0.0^{\prime}$ & & & & -0.20 & \\
\hline$\sigma_{\varepsilon 2}$ & $(0$. & & $(0$. & & & & & \\
\hline
\end{tabular}

Notes; $* * *, * *$ and $*$ indicate significance on a $1 \%, 5 \%$ and $10 \%$ level, respectively. Standard errors in brackets. Time and industry dummies are included. 